\title{
The Uitkomst intrusion and Nkomati Ni-Cu-Cr-PGE deposit, South Africa: trace element geochemistry, Nd isotopes and high-precision geochronology
}

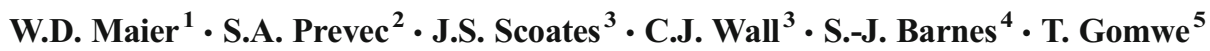

Received: 18 November 2015 / Accepted: 25 January 2017 /Published online: 23 March 2017

(C) The Author(s) 2017. This article is published with open access at Springerlink.com

\begin{abstract}
The Uitkomst intrusion is a tubular maficultramafic layered body that hosts one of South Africa's largest Ni-Cu-Cr-PGE deposits, Nkomati. The sulphide ore occurs in the form of massive lenses in the immediate quartzitic footwall and as disseminations within peridotite. The chromite ore forms an up to $\sim 10$-m-thick layer in the lower portion of the intrusion. Uitkomst has generally been interpreted as a magma conduit, possibly related to the Bushveld event. Here, we present a new high-precision U-Pb zircon date of $2057.64 \pm 0.69 \mathrm{Ma}$ that overlaps with the age of the Merensky Reef of the Bushveld Complex and thus demonstrates a coeval relationship between the intrusions. Based on incompatible trace elements as well as $\mathrm{O}$ - and $\mathrm{Nd}$ isotope data ( $\varepsilon \mathrm{Nd}-4.5$ to -6.2 ), we show that the Uitkomst parent magmas were contaminated with up to $20 \%$ Archean upper crust prior to emplacement, and with up to $15 \%$ dolomitic country rock
\end{abstract}

Editorial handling: M. Fiorentini

Electronic supplementary material The online version of this article (doi:10.1007/s00126-017-0716-x) contains supplementary material, which is available to authorized users.

W.D. Maier

MaierW@ cardiff.ac.uk

1 School of Earth and Ocean Sciences, Cardiff University, Cardiff, UK

2 Department of Geology, Rhodes University, Grahamstown, South Africa

3 Department of Earth, Ocean and Atmospheric Sciences, University of British Columbia, Vancouver, Canada

4 Sciences de la Terre, Université du Québec à Chicoutimi, Chicoutimi, Canada

5 Val-d'Or, Québec, Canada during emplacement. Ore formation at Nkomati was critically aided by substantial devolatisation and removal of dolomitic floor rocks leading to hydrodynamic concentration of sulphide and chromite during slumping of crystal mushes into the trough-like centre of the subsiding intrusion and its footwall.

\section{Introduction}

Nkomati is one of South Africa's largest magmatic Ni-Cu-PGE and chromite ore deposits. The mined-out massive sulphide deposit contained 2.3 Mt. @ 2.69\% Ni, 1.4\% Cu, 1.7 ppm Pt, $4.29 \mathrm{ppm} \mathrm{Pd}, 0.21 \mathrm{ppm} \mathrm{Rh}$, and $0.19 \mathrm{ppm} \mathrm{Au}$. The disseminated sulphides represent a resource of $407 \mathrm{Mt}$. @ 0.35\% Ni, $0.13 \% \mathrm{Cu}$ and $0.63 \mathrm{ppm}$ PGE (Mudd 2012). In addition, the Uitkomst intrusion originally contained a total measured and indicated resource of $6.23 \mathrm{Mt}$. of chromite ore with a grade of $33.47 \% \mathrm{Cr}_{2} \mathrm{O}_{3}$ that is now largely mined out (African Rainbow Minerals, http://arm.co.za/im/files/presentations/2007 /nkomati_site_visit24oct07.pdf). The intrusion has been interpreted as a magma feeder conduit based on its tubular shape, the large proportion of sulphide and chromite to silicate, and the lack of systematic upward differentiation in most of the ultramafic units (Gauert et al. 1995; Gauert 1998). Most previous authors proposed that Uitkomst was part of the Bushveld event, in view of broadly similar lithologies and mineral compositions in the intrusions. However, until recently, this model lacked clear geochronological support. De Waal et al. (2001) determined an age of $2044 \pm 8 \mathrm{Ma}$, not overlapping with recent ages for the Bushveld (2055-2056 $\pm \sim 1 \mathrm{Ma}$, Zeh et al. 2015; $2056.88 \pm 0.41-2057.04 \pm 0.55$ $\mathrm{Ma}$, Scoates and Wall 2015). The multi-grain baddeleyite age for Uitkomst of Wabo et al. $(2015,2054.5 \pm 7 \mathrm{Ma})$ shows better overlap with the Bushveld event, but still lacks sufficient precision. 
Here, we present a new precise age of the Uitkomst intrusion that overlaps with the age of the Merensky Reef of the Bushveld Complex. We also provide a detailed account on the concentration of incompatible trace elements and $\mathrm{Nd}$ isotopes and use these data to model the crystallisation history of the intrusion and the nature of its mantle source. In addition, we document rock textures based on which we propose a new mechanism of ore formation, via downward percolation of sulfidic crystal slurries into the devolatising dolomitic floor rocks, and hydrodynamic sorting of chromite-bearing slurries that sag into the subsiding trough-like lower portion of the magma chamber.

\section{Regional geology}

The Uitkomst intrusion is located $250 \mathrm{~km}$ east of Pretoria (Fig. 1a). It is a chonolithic body measuring approximately $0.8 \mathrm{~km}$ in height and width and at least $8 \mathrm{~km}$ in length (Fig. 1b). The chonolith consists of a relatively narrow (approximately $500 \mathrm{~m}$ wide) trough-like segment at the base which is overlain by a somewhat wider upper segment (Fig. 1c, d). Geophysical data indicate considerable extension of the body along plunge, towards the NW, recently confirmed by drilling (Yudovskaya et al. 2015). The intrusion was concordantly emplaced along the base and lower portion of gently $\left(5-10^{\circ}\right) \mathrm{WNW}$-dipping dolomite and shale belonging to the lowermost portion of the Early Proterozoic Transvaal Supergroup (Gauert et al. 1995). In most exposures, these rocks are underlain by Archean basement consisting of the 3220 Ma Nelshoogte Granite (Oosthuysen 1970), a biotiterich trondhjemite gneiss containing younger syenite intrusions. Locally, an intervening unit of basaltic lavas, immature polymictic quartzites and shales, and tuffs occurs between the Tranvaal Supergroup and the basement. These rocks are interpreted to belong to the Godwan Formation of the Ventersdorp Supergroup (Hornsey 1999).

The detailed stratigraphy of the host rocks to the Uitkomst intrusion has been described by Gauert et al. (1995) and Gauert (1998). The intrusion is hosted by the lower portion of the Transvaal Supergroup. The first unit above the Archean basement is a 2-m-thick quartzite, belonging to the Black Reef Formation of the Wolkberg Group. This is overlain by 2-3 m of sheared dolomite, termed the "basal shear" by mine geologists. The sheared dolomite is overlain by $3 \mathrm{~m}$ of coarsegrained quartzite of the Oaktree Member of the Malmani Subgroup, forming the immediate floor of the intrusion in much of the studied area. Next are 145-300 m of dolomitic rocks of the remainder of the Malmani Subgroup, dated at $2550 \pm 3 \mathrm{Ma}(\mathrm{Pb}-\mathrm{Pb}$ single zircon, Walraven and Martini 1995). The dolomite is overlain by a chert-conglomerate layer (termed the Bevets Conglomerate Member) up to $10 \mathrm{~m}$ in thickness, belonging to the Rooihoogte Formation, and then $>1200 \mathrm{~m}$ of graphitic shales with minor quartzite and
Fig. 1 a Location of Uitkomst Complex relative to the Bushveld Complex. b Simplified local geological map. c Schematic shape of Uitkomst intrusion, including chromite and sulphide mineralization. d Basal portion of intrusion, including sulphide mineralized zones termed (1) the Massive Sulphide Body (MSB), (2) the Basal Mineralised Zone (BMZ) within the Basal Gabbronorite Unit, (3) the Main Mineralised Zone (MMZ) within the Lower Peridotite Unit, and (4) the Chromititic Peridotite Mineralized Zone (PCMZ) within the Chromitiferous Harzburgite. a-c modified after Maier et al. (2004), D modified after Theart and de Nooy (2001)

ironstone belonging to the Timeball Hill Formation. It contains a laterally persistent quartzite horizon (the Klapperkop Quartzite, Fig. 1c) located a few $100 \mathrm{~m}$ above its base.

\section{Lithologies of the Uitkomst complex}

The Uitkomst intrusion has been intersected by numerous drill cores, but few of these cover the entire stratigraphy. One of the most complete profiles, intersecting the entire $\sim 850 \mathrm{~m}$ of intrusive stratigraphy and significant segments of its hanging wall and footwall rocks, is provided by drill core ( $\mathrm{SH} \mathrm{176),}$ located on the farm Slaaihoek, hosting the northwestern portion of the intrusion. Based mainly on this drill core and supplemented by data from the mine's large drill core database, an overview of the lithostratigraphy of the Uitkomst intrusion is provided in the following section.

At the base of the intrusion is the Basal Gabbronorite unit (BG). Its average thickness across the Uitkomst intrusion is $6 \mathrm{~m}$, but locally it can reach up to $12 \mathrm{~m}$ in thickness, or be absent. It has an aphanitic chilled margin at the bottom, ranging in thickness from 0.1 to $1.8 \mathrm{~m}$, underlain by a zone of felsic veining in banded hornfels (Fig. 2a, b). Sill-like offshoots of the basal gabbro extend for up to $400 \mathrm{~m}$ into the country-rocks (Fig. 1d). Gauert (1998) observed gabbroic rocks possibly belonging to the $\mathrm{BG}$ along the sidewall of the Uitkomst chonolith. Most of the remainder of the BG consists of medium-grained quartz-bearing gabbronorite with up to $10 \%$ disseminated sulphides, mainly chalcopyrite and pyrrhotite, as well as less abundant pentlandite (Fig. 2c). Several lenses of massive sulphide, up to $150 \mathrm{~m}$ long and $15 \mathrm{~m}$ high, are located in the immediate floor rocks (Fig. 2d), separated from the BG by between 5 and $30 \mathrm{~m}$ of sheared dolomite and quartzite (Theart and de Nooy 2001; Hornsey 1999).

The Basal Gabbronorite is overlain by the up to $\sim 50-\mathrm{m}-$ thick lower peridotite (LP), a heterogenous unit that contains medium- to coarse-grained, pervasively altered harzburgite, lherzolite, wehrlite and websterite. Some of these highly magnesian rocks have very low $\mathrm{Cr}$ contents (e.g., $<200$ ppm in samples SH176-57 and 56). We argue that these are calcsilicates, comparable to the parapyroxenites of the Platreef (McDonald and Holwell 2011). The LP may directly overlie Oaktree quartzite, suggesting local erosion of the BG by the LP (Gauert 1998). Metamorphosed xenoliths of 


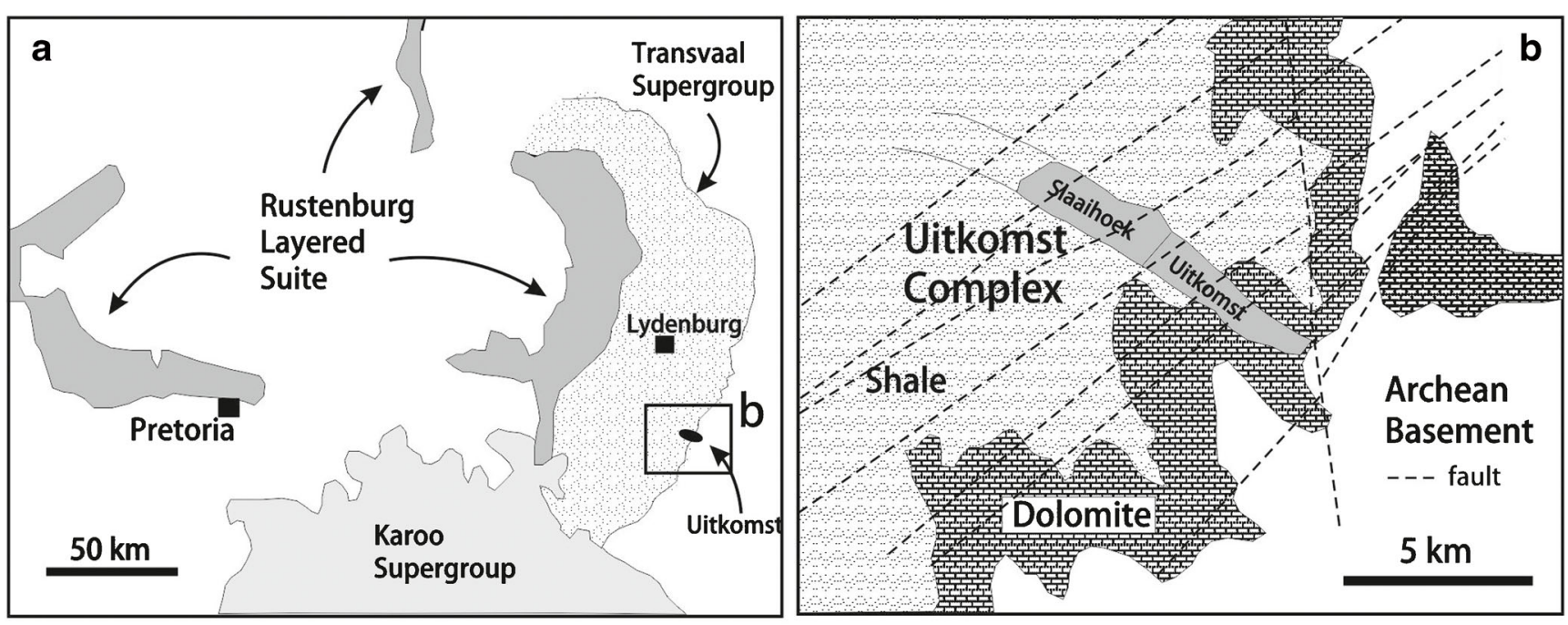

C
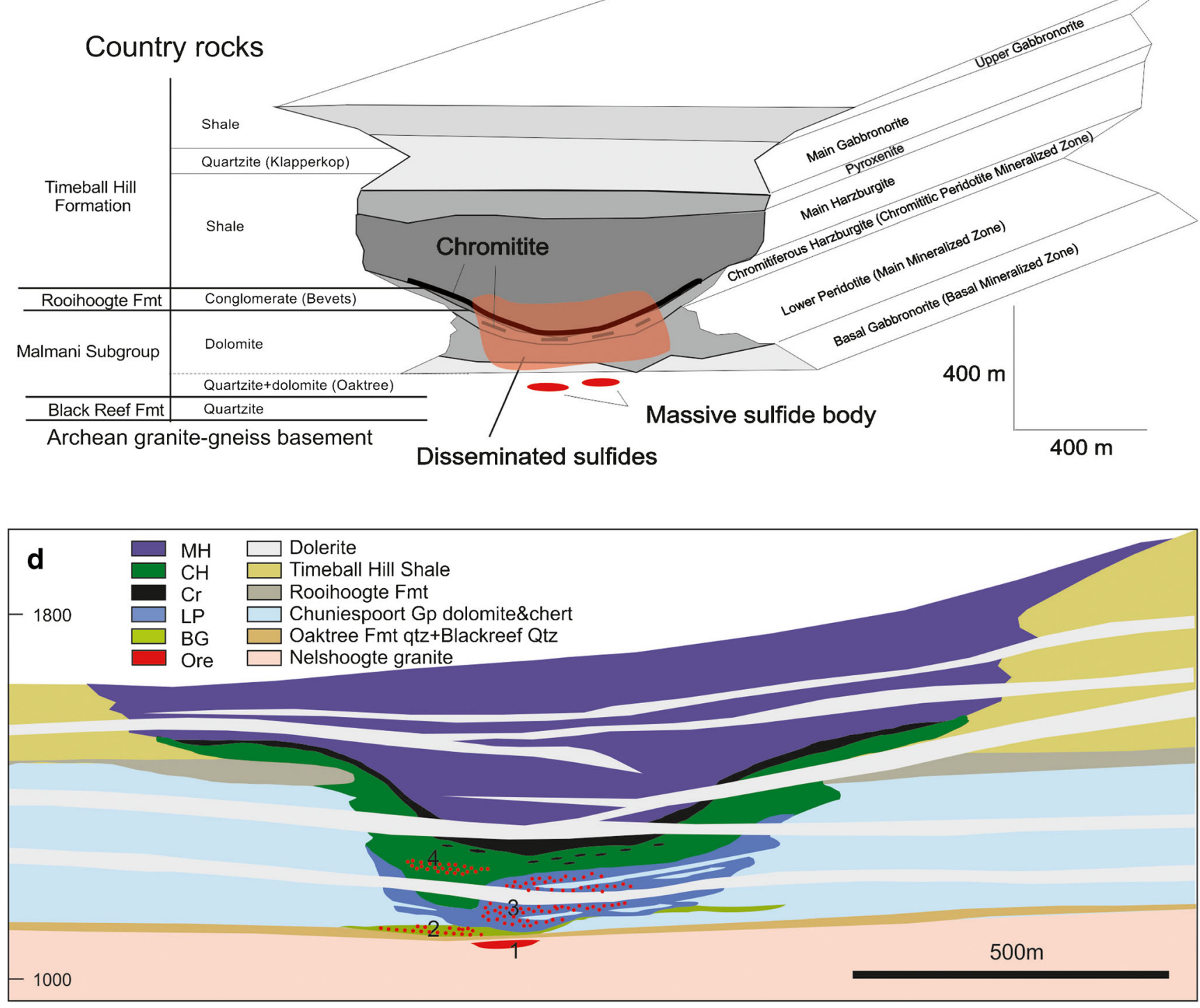

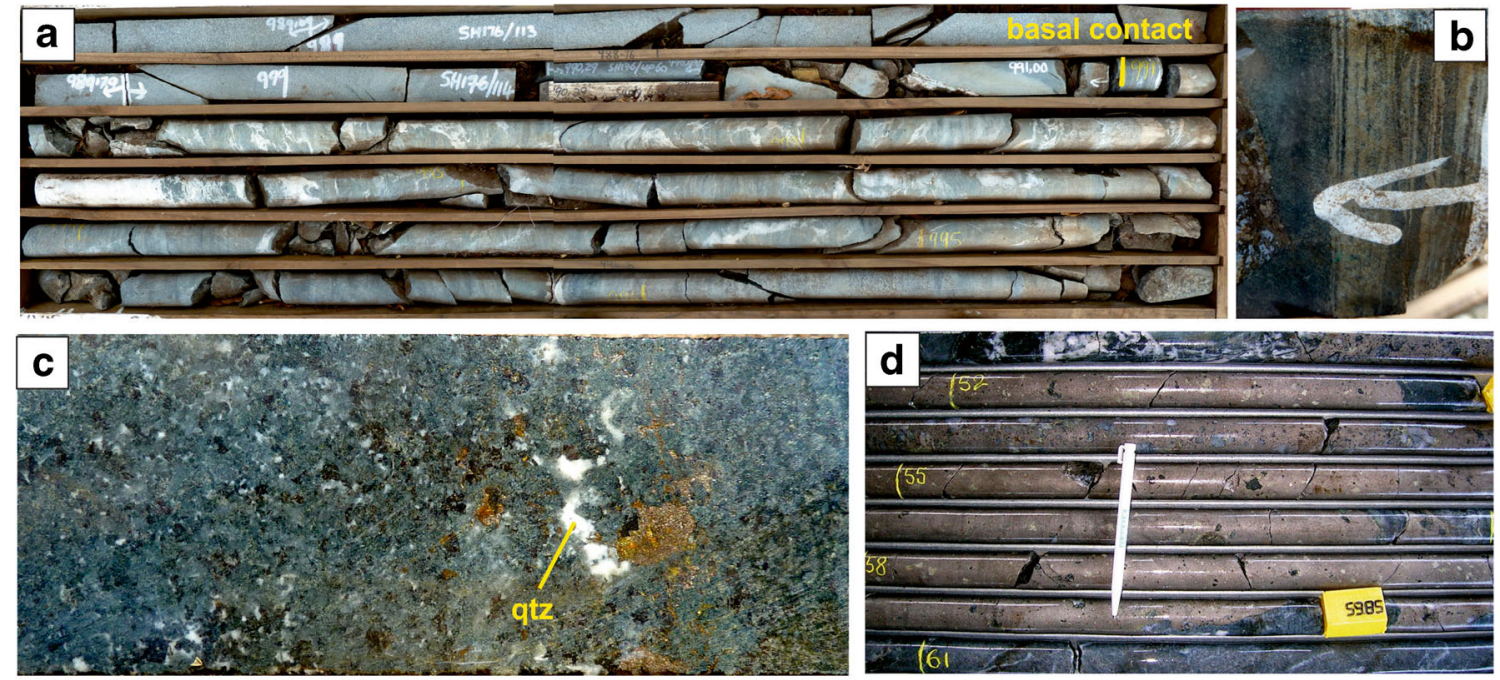

Fig. 2 a Basal chilled margin of Uitkomst intrusion. b Close-up of basal contact. c Sulphides in Basal Gabbronorite Unit. d Massive sulphide body intersected in drill core

dolomite can constitute up to half of the volume of the LP (Fig. 1d), particularly in the northwestern portion of the intrusion. The primary lamination of, by far, the majority of the xenoliths intersected in the LP is horizontal or sub-parallel relative to the basal contact of the intrusion. Many form highly elongated fragments, or laterally extensive rafts, that may represent side wall pendants connected in 3D (Fig. 3a; Hornsey 1999; Hulley 2005). Sulphides consist of pyrrhotite and relatively less abundant chalcopyrite and pentlandite. They mostly occur disseminated, except in wehrlite, where net-textured ore with up to 30 modal \% sulphide is common. Locally, the sulphides form networks between sub-rounded fragments of wehrlite (Fig. 3b). In many cases, sulphides are concentrated adjacent to metamorphosed dolomite xenoliths (Fig. 3c) or inject into the dolomite (Fig. 3d), possibly reflecting sulphide melt mobility during devolatisation of the dolomite.

The overlying Chromitiferous Harzburgite $(\mathrm{CH})$ is between 30 - and $60-\mathrm{m}$ thick, averaging $35 \mathrm{~m}$ (Theart and de Nooy 2001). Like the LP, it mostly occupies the dolomitehosted lower trough of the Uitkomst chonolith, but in contrast to the LP, the $\mathrm{CH}$ contains only rare dolomite xenoliths. The unit onlaps the levees at the base of the widened upper portion of the Uitkomst chonolith where it overlies the Rooihoogte and Timeball Hill formations (Fig. 1d). The rocks of the $\mathrm{CH}$ are pervasively altered mediumgrained harzburgitic meso- and orthocumulate containing up to $5 \%$ disseminated sulphides and numerous lenses, schlieren, and fragments of massive and disseminated chromitite (Fig. 4), particularly in the central portion of the lower trough (Avmin unpublished internal reports). The shape, orientation and composition of the fragments is highly variable, suggesting that the rocks represent magmatic breccias. In the southeastern part of the intrusion, several massive chromitite layers occur towards the top of the $\mathrm{CH}$ (Fig. 5a). The cross-section published by Theart and de Nooy (2001) suggests that the chromitite layer becomes progressively thicker towards the centre of the intrusion, but Gauert (1998) also described thick chromitite at the margin and directly overlying the sidewall of the chonolith. Thus, whether there is a systematic variation in thickness of the chromitite across the intrusion remains unclear. On the farm Uitkomst (Fig. 1b), the chromitite may reach a thickness of up to $15 \mathrm{~m}$, ascribed to thrust duplication (Gauert 1998).

Next is the Main Harzburgite unit (MH), with an average thickness of $264 \mathrm{~m}$. It consists mainly of mediumgrained poikilitic harzburgite (Fig. 5b, c), as well as rare dunite and several thin (up to $10 \mathrm{~cm}$ ) chromitite layers and schlieren (Fig. 5b). The latter are interpreted to be synmagmatic, as they are closely associated with undeformed orthopyroxene oikocrysts. Most of the rocks of the $\mathrm{MH}$ are pervasively serpentinised meso and orthocumulates. Country rock xenoliths are largely absent. The lower part of the MH is made up of multiple sub-units characterised by basal chromitite layers that are directly overlain by disseminated sulphides and then relatively sulphide poor peridotite (H. Theart, pers. com, April 2015). An additional sulphide-enriched horizon is located some $50-90 \mathrm{~m}$ below the top of the MH.

The MH has a gradational and irregular contact to the overlying Pyroxenite unit (PX; Fig. 5c), with harzburgite and pyroxenite being interlayered over approximately $1-2 \mathrm{~m}$. The PX is $60-70-m$ thick and consists of a relatively homogenous, medium-grained, orthopyroxenite orthocumulate. Appreciable olivine occurs only in the basal few metres. Up to $1 \mathrm{wt} \%$ disseminated sulphides (pyrrhotite, pentlandite and chalcopyrite) occur in the upper portion of the unit, hosting anomalous PGE (up to $0.15 \mathrm{ppm} \mathrm{Pt}+\mathrm{Pd}+\mathrm{Au}$ ) and $\mathrm{Cu}$ 

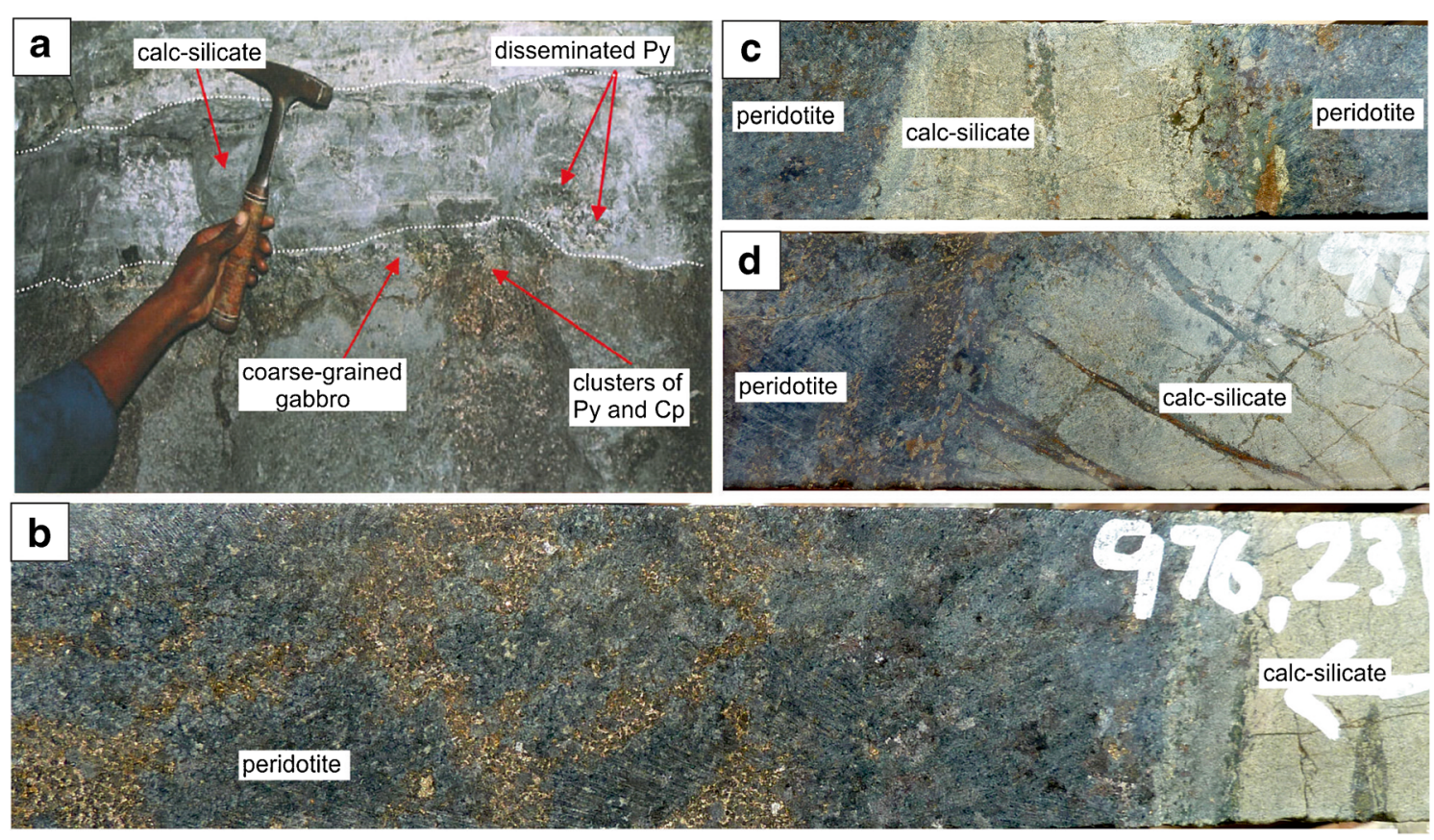

Fig. 3 Photographs of the Lower Peridotite Unit. a Elongated calcsilicate xenolith, bulk sample drive (photo from Hulley 2005). b Net-textured sulphides between fragments of calcsilicate $(976.1 \mathrm{~m}$, drill core
SH176). c Concentration of sulphide along contact with calcilicate, $975.3 \mathrm{~m}, \mathrm{SH} 176$. d Injection of sulphide into calcsilicate, $977.05 \mathrm{~m}$, SH176

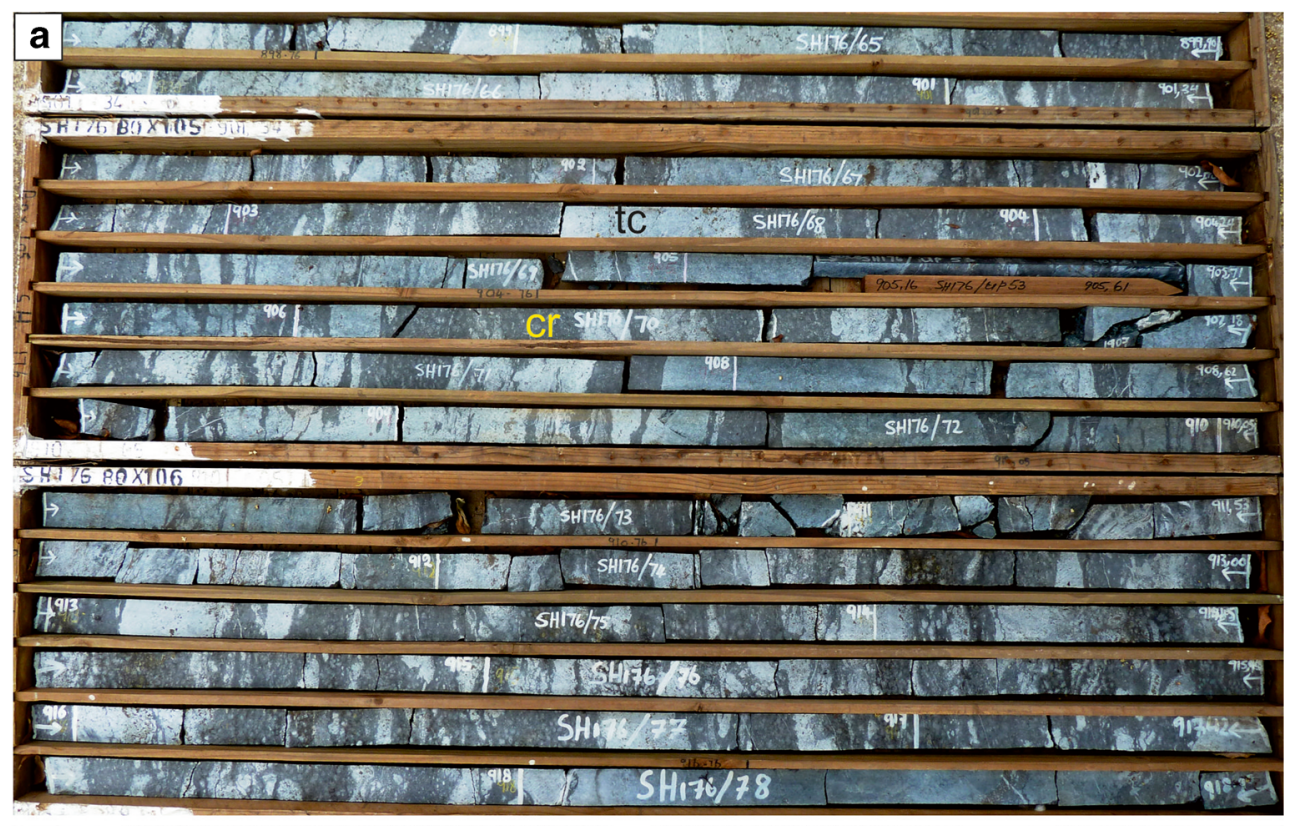

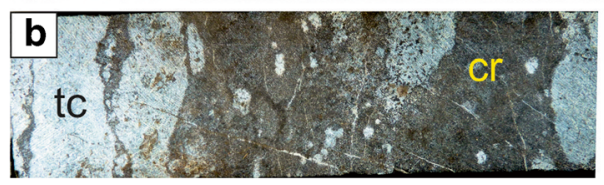

Fig. 4 a Intersection of the Chromitiferous Harzburgite Unit, drill core SH176, illustrating the remarkable thickness of the chromite-rich interval $(\sim 20 \mathrm{~m})$. b Close-up of structures within the $\mathrm{CH}$. Note sub-rounded fragments of talc-carbonate altered harzburgite within chromitite. c Sub-

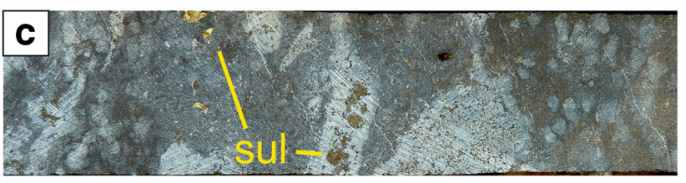

angular or rounded, variably sulphide mineralized fragments of altered harzburgite within chromitite, interpreted as a magmatic breccia. See text for further discussion 

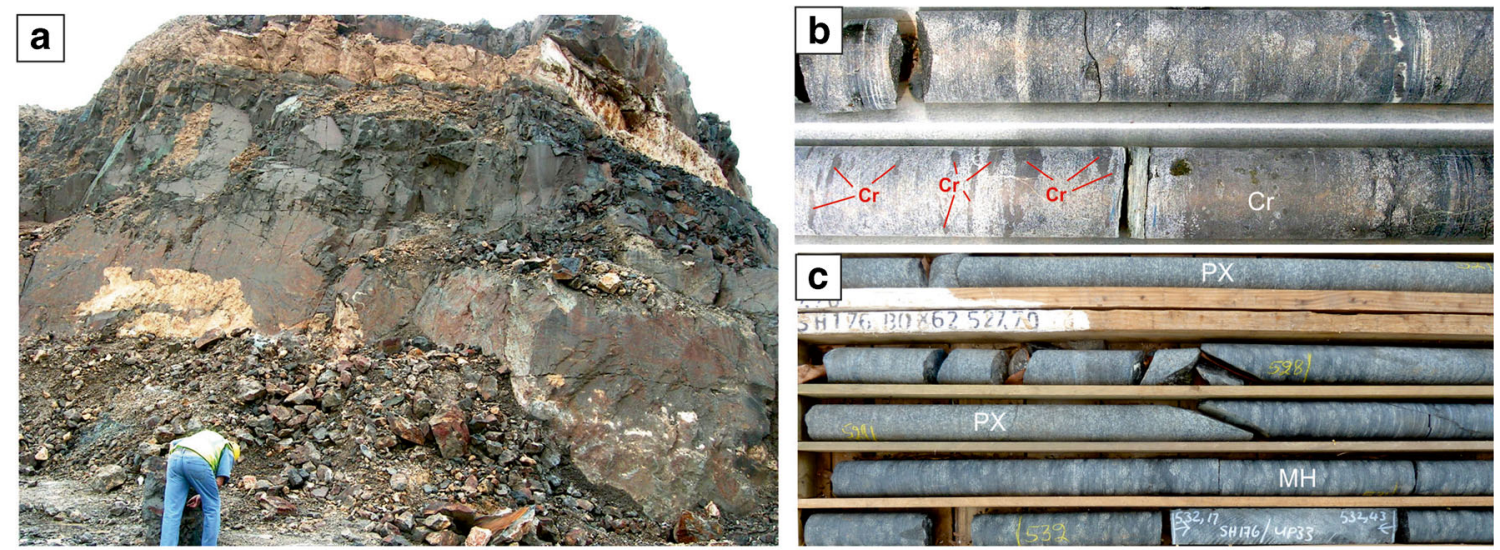

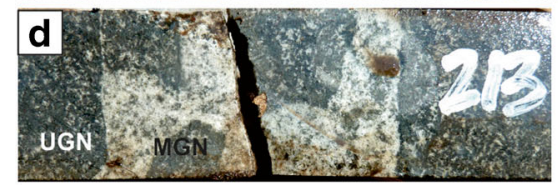

Fig. 5 a Main chromitite of Uitkomst intrusion, main open pit. b Drill core intersections of $\mathrm{MH}$ showing layers, lenses and schlieren of chromitite. c Transition from MH to PX. Note lens of harzburgite

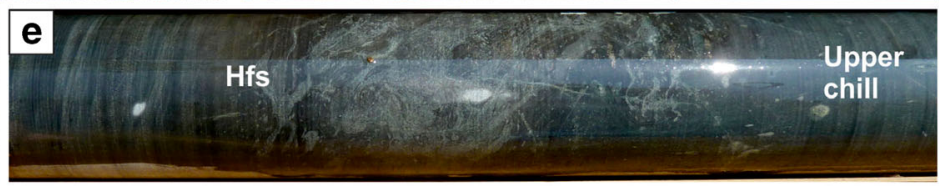

within pyroxenite. d Contact between MGN and UGN, $211.4 \mathrm{~m}$, SH176. e Upper chilled margin of intrusion, $135.5 \mathrm{~m}$, SH176
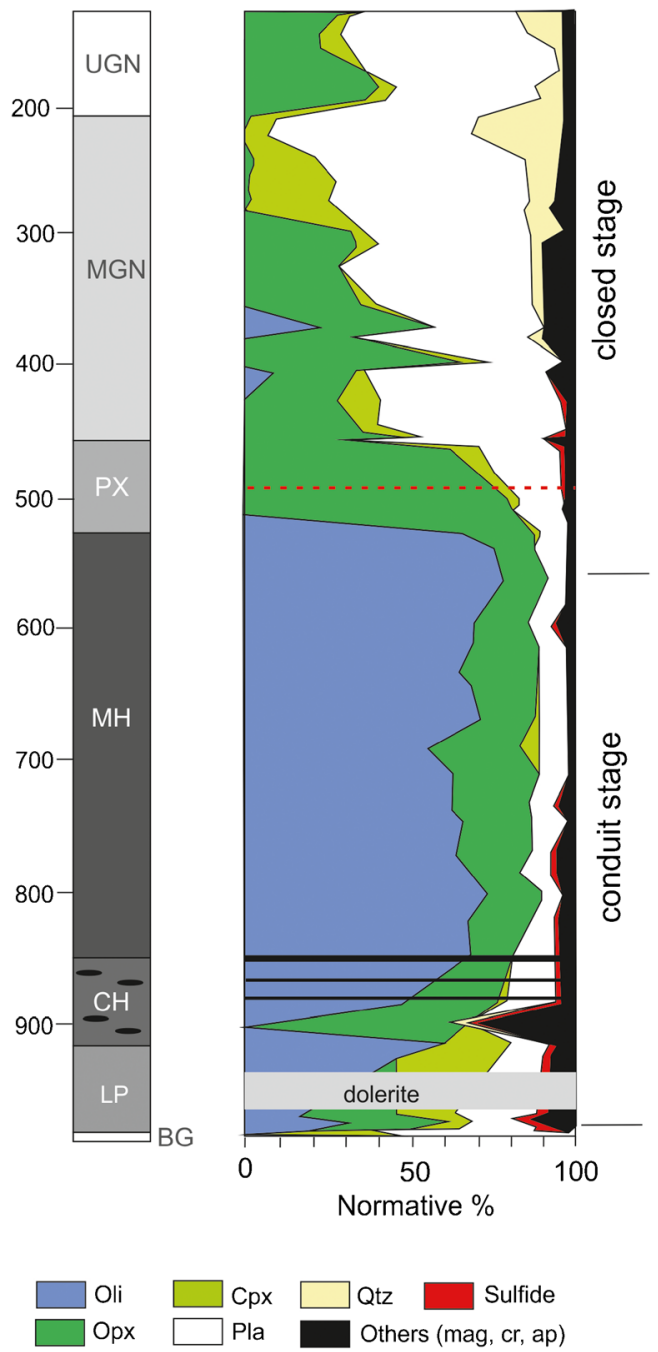

Fig. 6 CIPW normative mineral proportions of drill core SH 176 
Cape Town, using a Perkin/Elmer/Sciex Elan 6000 instrument equipped with an acid resistant cross flow nebulizer, a Ryton TM Scott-type spraychamber and a Perkin Elmer AS 90 autosampler. Samples were digested in a mixture of $\mathrm{HNO}_{3}$ and HF in heated, closed Teflon beakers, followed by evaporation to dryness. Accuracy and precision, as determined by analysing standards BCR-1 and BHVO-1, are 1-3\% for most elements, except for $\mathrm{Nb}(\sim 5 \%)$ and $\mathrm{Th}(\sim 6 \%)$. Whole rock data, including CIPW norms are given in Online Resource 1.

Samarium and $\mathrm{Nd}$ analyses were conducted at McMaster University (Hamilton, Canada), using a combination of cation exchange and HDEHP-column chromatography. This followed sample powder dissolution in $\mathrm{HF} / \mathrm{HNO}_{3}$ and conversion to chloride in $\mathrm{HCl}$, according to the method described in Prevec et al. (1991). Mass spectrometry was conducted using doublefilament ionisation of REE-chloride in a VG354 mass spectrometer in dynamic multicollector mode, with $\mathrm{Nd}$ data normalised to a ${ }^{146} \mathrm{Nd} /{ }^{144} \mathrm{Nd}$ ratio of 0.7219 . $\mathrm{Sm} / \mathrm{Nd}$ concentrations and ratios were determined by isotope dilution on splits of the same dissolutions as were used for isotope ratios. ${ }^{143} \mathrm{Nd} /{ }^{144} \mathrm{Nd}$ ratios of La Jolla $\mathrm{Nd}$ metal standard were $0.511859 \pm 0.000019(2 \sigma, n=10)$ over the course of this study (September 2010 to January 2011), and a replicate dissolution of one sample showed less variation than this.

The geochronological work, including sample preparation, mineral separate extraction, chemical abrasion techniques and measurement of isotope ratios of individual zircon grains was completed at the Pacific Centre for Geochemical and Isotopic Research at the University of British Columbia, Vancouver, Canada. From the $86 \mathrm{~g}$ of sample SH176-10 that was processed from a cut piece of quarter drillcore, the least magnetic split (N2) yielded approximately 100 zircon grains. All handpicked zircon grains ( $250 \mu \mathrm{m}$ in length) were elongate, euhedral, clear, and colourless to light pink with minor amounts of mineral and fluid inclusions. Chemical abrasion-isotope dilutionthermal ionisation mass spectrometry procedures are modified from Mattinson (2005) and adapted at PCIGR as outlined in Scoates and Wall (2015). Isotopic ratios were measured on a modified single collector VG-54R or $354 \mathrm{~S}$ (with Sector 54 electronics) thermal ionisation mass spectrometer equipped with analogue Daly photomultipliers.

Uranium fractionation was determined directly on individual runs using the EARTHTIME ET535 mixed ${ }^{205} \mathrm{~Pb}^{233} \mathrm{U}-{ }^{235} \mathrm{U}$ isotopic tracer and $\mathrm{Pb}$ isotopic ratios were corrected for fractionation of $0.25 \% / \mathrm{amu} \pm 0.03 \%(2 \sigma)$ based on replicate analyses of NBS-982 reference material (Scoates and Wall 2015). All dates were Th-corrected for initial disequilibrium in ${ }^{230} \mathrm{Th} /{ }^{238} \mathrm{U}$ using a Th/ $\mathrm{U}_{\text {magma }}=3.5 \pm 1.5$ (Bushveld marginal rocks: Barnes et al. 2010) and ${ }^{238} \mathrm{U} /{ }^{235} \mathrm{U}=137.88$. Raw data were reduced using Tripoli (Bowring et al. 2011) and an Excel-based spreadsheet that employs the algorithms in Schmitz and Schoene (2007); all errors are quoted at the $2 \sigma$ level. The laboratory reproducibility during the data acquisition period was assessed by repeated analysis of EARTHTIME synthetic solutions. All analytical results are reported in Table 2. See Online Resource 2 for additional details on methodology.

\section{Results}

\section{Major and trace element geochemistry}

Selected whole rock major, minor, trace element and isotope data from drill core SH 176 are presented in Fig. 7. The petrological evolution of the intrusion is illustrated by variation in $\mathrm{Mg \#}$ (calculated by assuming a ratio of $\mathrm{FeO} / \mathrm{Fe}_{2} \mathrm{O}_{3}$ of 0.8 ). In the lowermost $200 \mathrm{~m}$ of the intrusion (comprising the BG, LP, $\mathrm{CH}$, and the basal portion of the $\mathrm{MH}$ ) the rocks become progressively less evolved, somewhat analogous to the basal reversal observed in many layered intrusions such as Muskox (Francis 1994) or the Bushveld (Teigler and Eales 1996). In the $\mathrm{MH}$, the $\mathrm{Mg \#}$ stays remarkably constant before it decreases through the PX and the MGN. At the base of the

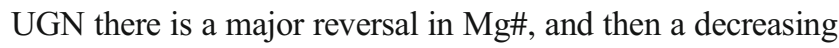
trend to the top contact of the intrusion. The upper chilled margin has a broadly similar $\mathrm{Mg \#}$ as the lower one.

$\mathrm{TiO}_{2}$ and $\mathrm{P}_{2} \mathrm{O}_{5}$ contents show a different pattern, with a progressive decrease through the $\mathrm{BG}, \mathrm{LP}$ and $\mathrm{CH}$, the lowest values in the $\mathrm{MH}$ and the PX, and then a sharp increase midway through the MGN (Fig. 7). This is followed by decreasing $\mathrm{TiO}_{2}$ and $\mathrm{P}_{2} \mathrm{O}_{5}$ contents to the top of the intrusion.

Many of the incompatible trace elements such as $\mathrm{Zr}, \mathrm{Nb}$ and REE, show broadly similar trends as the incompatible minor elements, with upward decreasing levels in the basal portion, consistently low levels in the $\mathrm{MH}$, increasing concentrations towards the upper portion of the intrusion, and a reversal at the base of the UGN. However, Th, U and Rb form an exception to this trend in that they show the highest levels at the very top of the intrusion. Notably, $\mathrm{K}_{2} \mathrm{O}$ and $\mathrm{Rb}$ are strongly depleted in the uppermost portion of the MGN. Ce/Sm ratios (9-12) show relatively little systematic variation throughout the intrusion and are broadly in the range of the Bushveld LZ and LCZ (Maier et al. 2013).

The primitive-mantle normalised multi-element variation diagrams of all rocks are relatively fractionated, with pronounced negative $\mathrm{Nb}-\mathrm{Ta}, \mathrm{P}$ and $\mathrm{Sr}$ anomalies, and positive $\mathrm{Pb}$ anomalies (Fig. 8). The patterns of the cumulate rocks generally match those of the chilled margins. The latter resemble Bushveld B1 magma (Barnes et al. 2010), but the basal chilled margin has a positive $\mathrm{K}$ anomaly and it lacks the negative $\mathrm{Ti}$ anomalies that are characteristic of all Bushveld magmas. The trace element patterns of the chilled margins show no resemblance with Bushveld B2 and B3 magmas (Barnes et al. 2010). One notable feature of the plots is the 

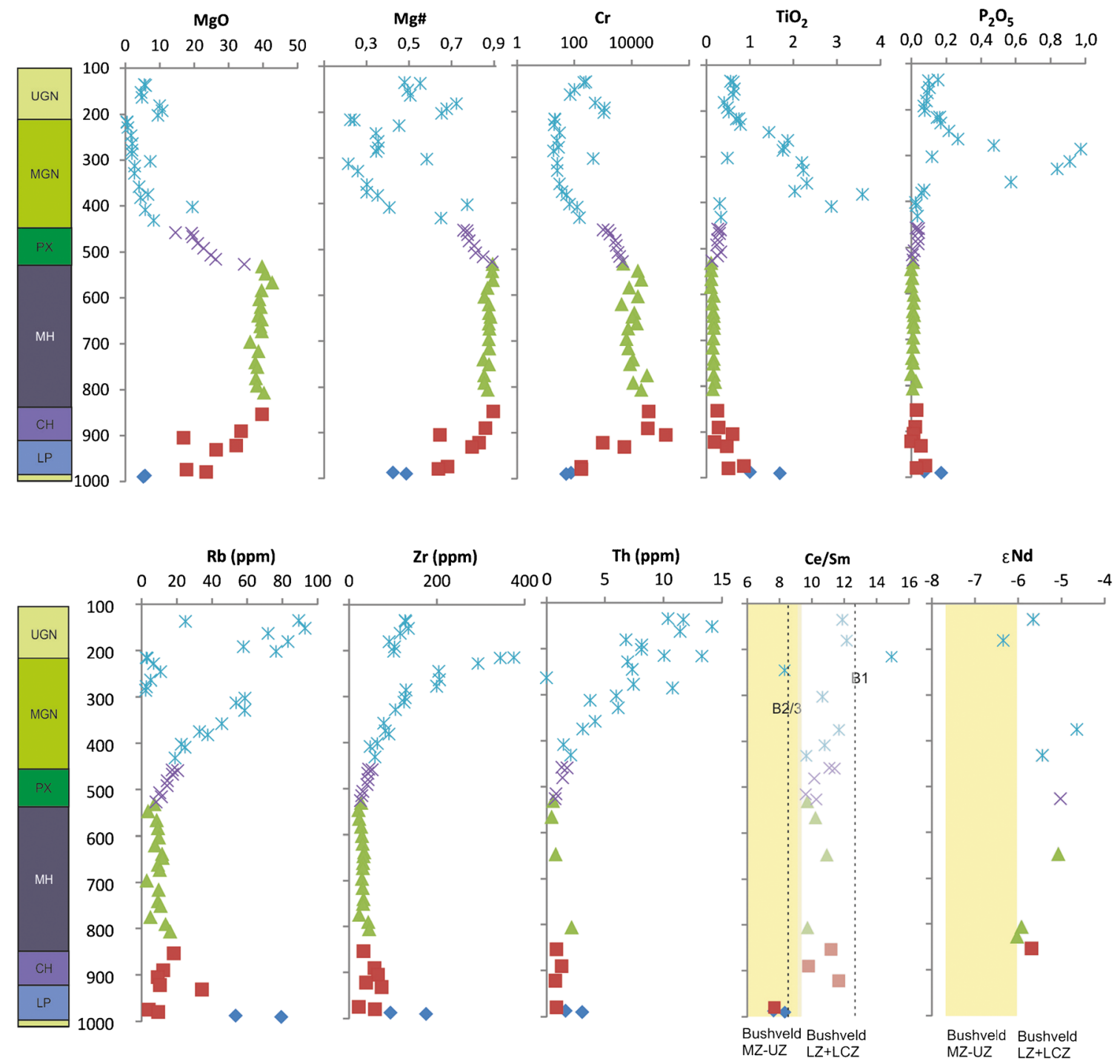

Fig. 7 Lithophile major and trace element data, as well as $\varepsilon N d$, in drill core SH176. Compositions of Bushveld B1-3 magmas are from Barnes et al., (2010), and $\varepsilon \mathrm{Nd}$ and $\mathrm{Ce} / \mathrm{Sm}$ data of Bushveld LZ, CZ, MZ and UZ from Maier et al. (2000, 2013)

similarity in the shapes of the trace element patterns with those of Bushveld cumulates of the Lower Zone (LZ) and Lower Critical Zone (LCZ), although most Uitkomst rocks have higher incompatible trace element contents, with the exception of the uppermost $\mathrm{MH}$ that shows close overlap with the Bushveld LZ.

\section{Neodymium isotope data}

The $\varepsilon \mathrm{Nd}$ values of the Uitkomst rocks vary between -4.5 to -6.2 (Table 1) and there is no systematic variation with height (Fig. 7). The values show good overlap with the LZ and LCZ of the Bushveld Complex, but are more radiogenic than those for the Upper Critical Zone (UCZ) and Main Zone (MZ; Maier et al. 2000). The data are plotted against $\delta^{18} \mathrm{O}$ for mineral separates from the same samples (Sarkar et al. 2008, and corrected for fractionation according to the method outlined in
Online Resource 3) in Fig. 9a, where $\delta^{18} \mathrm{O}$ ranges between +5.2 and $+8.7 \%$.

\section{Geochronology}

The age of the Uitkomst intrusion was determined on zircon in sample SH176-10. This is a medium- to coarse-grained amphibole quartz monzodiorite from the upper part of the Main Gabbronorite. It consists of approximately $50 \mathrm{vol} \%$ strongly sericitized plagioclase, $15 \%$ alkali feldspar showing abundant tartan twinning, 15\% quartz, $10 \%$ green amphibole, 5\% ilmenite, $3 \%$ titanite, $2 \%$ interstitial carbonate, $1 \%$ apatite and abundant accessory zircon. Secondary blue chlorite and calcite have replaced amphibole and plagioclase, respectively. Trace sulphides comprise pyrrhotite and chalcopyrite. Zircon occurs as abundant euhedral crystals $(50-250 \mu \mathrm{m}$ in diameter) 

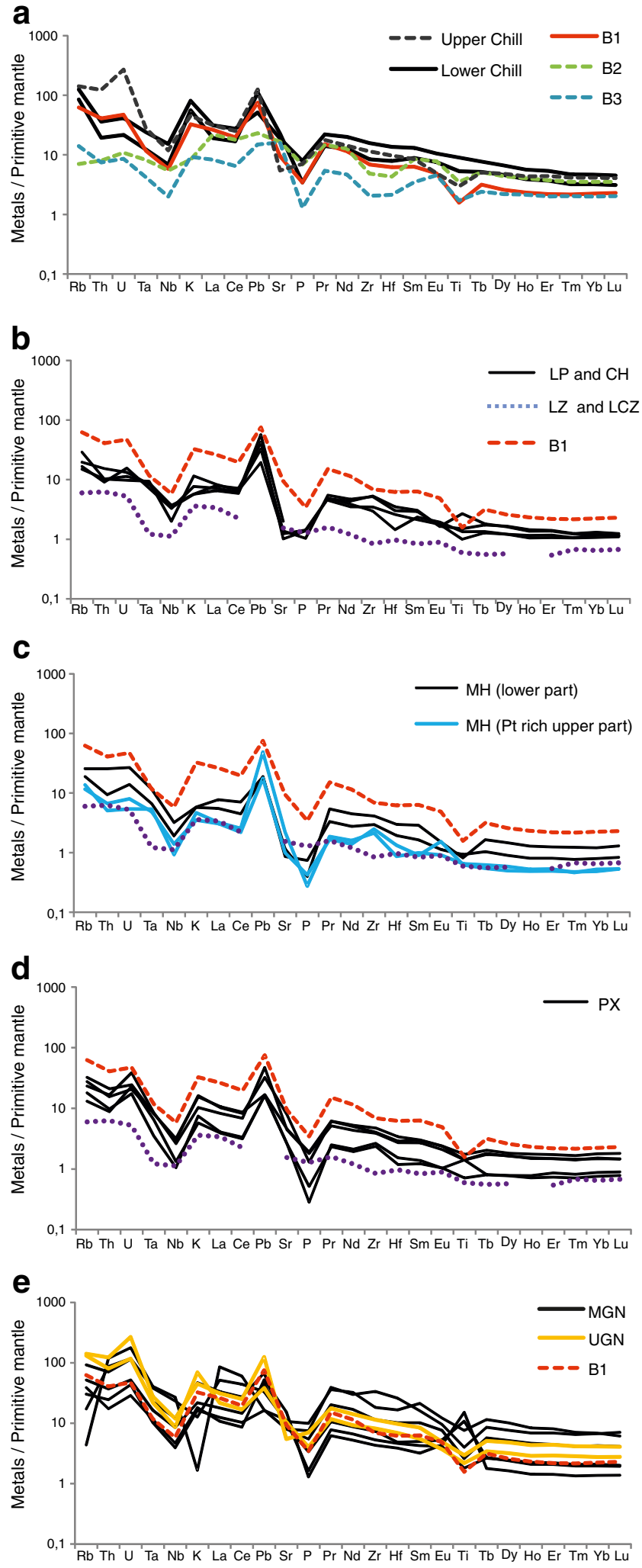

Fig. 8 Multi-element variation diagrams of Uitkomst rocks, normalised to primitive mantle (Sun and McDonough 1989). a Lower and upper chilled margin as well as Bushveld parent magmas (from Barnes et al. 2010). b Lower Pyroxenite and Chromitiferous Harzburgite units. c Main Harzburgite Unit. d Pyroxenite Unit. e Upper Gabbronorite Unit along the margins of amphibole clots in contact with plagioclase (Fig. 10).

The U-Pb errors are reported in the $\pm \mathrm{X} / \mathrm{Y} / \mathrm{Z}$ format of Schoene et al. (2006) with internal error in the absence of all systematic errors $( \pm X)$, including tracer calibration error $( \pm \mathrm{Y})$, and including uncertainty due to decay constant errors $( \pm \mathrm{Z})$. The $\mathrm{U}$ and $\mathrm{Pb}$ concentrations for the chemically abraded zircon grain fragments (A-D) from sample SH176/ Up10 range from 21 to 313 and 9-128 ppm, respectively, with $\mathrm{Th} / \mathrm{U}=0.40-0.47$ (Table 2). The U-Pb data for three of the four chemically abraded grains are concordant $(\mathrm{D}=0.08$ to $-0.18 \%)$ and they yield a range of ${ }^{207} \mathrm{~Pb} /{ }^{206} \mathrm{~Pb}$ ages from 2057.2 to $2058.5 \mathrm{Ma}$ (Table 2). The weighted mean ${ }^{207} \mathrm{~Pb} /{ }^{206} \mathrm{~Pb}$ age based on the results from the three concordant fractions (A, C, D) is $2057.64 \pm 0.69 / 0.69 / 2.43 \mathrm{Ma}(2 \sigma, \mathrm{MSWD}=0.76$; Fig. 11) and is interpreted as the crystallisation age of the diorite. The results for fraction $\mathrm{B}$ were excluded from the weighted mean calculation due to their slightly higher discordance $(-0.36 \%)$.

The use of two decimal places in the date and uncertainty indicates that these are significant figures and that the analytical precision is precise to $\pm 690,000$ years. At UBC, the Schmitz and Schoene (2007) method, or S\&S, is used for the derivation of isotope ratios, errors, and error correlations related to $\mathrm{U}-\mathrm{Pb}$ isotopic analysis by thermal ionisation mass spectrometry (TIMS). Most U-Pb labs worldwide now use this data reduction procedure, which allows the direct comparison of results. The S\&S method takes into account all sources of analytical uncertainty and propagates uncertainty through all calculations.

The new U-Pb zircon age for the Uitkomst diorite of $2057.64 \pm 0.69$ Ma overlaps within uncertainty with a ${ }^{207} \mathrm{~Pb} /{ }^{206} \mathrm{~Pb}$ baddeleyite age of $2054.5 \pm 6.9 \mathrm{Ma}$ from a coarse-grained gabbro, taken from tailings, that likely represents the Main Gabbronorite (Wabo et al. 2015) and it is significantly older than the previous U-Pb zircon SHRIMP age of $2044 \pm 8 \mathrm{Ma}$ from a diorite also from the Main Gabbronorite (De Waal et al. 2001; Fig. 12). The ca. $2054 \mathrm{Ma}$ age determined in Wabo et al. (2015) should be considered a minimum age as it is based on a single $\mathrm{U}-\mathrm{Pb}$ analysis of a multi-grain baddeleyite fraction ( $\mathrm{D}=0.1 \%$ ) and it is possible that secondary zircon overgrowths tentatively identified on most of the separated baddeleyite grains by Wabo et al. (2015) are present even if they were not observed optically on the grains selected for analysis. The presence of secondary zircon overgrowths would result in mixed $\mathrm{U}-\mathrm{Pb}$ and $\mathrm{Pb}-\mathrm{Pb}$ ages that are younger than the baddeleyite crystallisation age (e.g., Rioux et al. 2010).

The new age directly links magmatic activity in the Uitkomst Complex to the Bushveld Complex (Fig. 12). The ca. $2057 \mathrm{Ma}$ age overlaps within uncertainty of CA-TIMS U- 
Table 1 Sm-Nd isotopic compositional data for the Uitkomst intrusion

\begin{tabular}{llllllllrr}
\hline & $\mathrm{Sm}(\mathrm{ppm})$ & $\mathrm{Nd}(\mathrm{ppm})$ & ${ }^{147} \mathrm{Sm} /{ }^{144} \mathrm{Nd}$ & ${ }^{143} \mathrm{Nd} /{ }^{144} \mathrm{Nd}$ & $\mathrm{Sm} / \mathrm{Nd}$ & $f S m / N d$ & $\mathrm{~T}_{\mathrm{CHUR}}(\mathrm{Ma})$ & $\varepsilon(0)$ & $\varepsilon(\mathrm{t})$ \\
\hline UP 1 & 3.15 & 15.47 & 0.1231 & 0.511360 & 0.2036 & -0.3741 & 2634 & -24.9 & -5.5 \\
UP 5 & 2.29 & 11.34 & 0.1219 & 0.511309 & 0.2018 & -0.3798 & 2695 & -25.9 & -6.2 \\
UP 19 & 2.29 & 1.19 & 0.1200 & 0.511370 & 0.1985 & -0.3898 & 2509 & -24.7 & -4.5 \\
UP 23 & 1.85 & 8.53 & 0.1312 & 0.511479 & 0.2171 & -0.3327 & 2683 & -22.6 & -5.3 \\
UP 32 & 0.54 & 2.54 & 0.1296 & 0.511479 & 0.2144 & -0.3408 & 2620 & -22.6 & -4.9 \\
UP 40 & 0.62 & 3.47 & 0.1246 & 0.511410 & 0.2061 & -0.3663 & 2585 & -24.0 & -4.9 \\
UP 49 & 1.05 & 5.07 & 0.1256 & 0.511380 & 0.1256 & -0.3613 & 2684 & -24.5 & -5.8 \\
UP 50 & 0.81 & 3.90 & 0.1259 & 0.511380 & 0.2084 & -0.3595 & 2698 & -24.5 & -5.9 \\
UP 51 & 0.84 & 4.29 & 0.1187 & 0.511300 & 0.1965 & -0.3961 & 2605 & -26.1 & -5.5 \\
UP 51D & 0.84 & 4.24 & 0.1191 & 0.511309 & 0.1971 & -0.3941 & 2599 & -25.9 & -5.4 \\
\hline
\end{tabular}

$\mathrm{ENd}(\mathrm{t})$ calculations were conducted for $2440 \mathrm{Ma}$, using a decay constant of $6.54 \times 10-12 \mathrm{y}-1$ for ${ }^{147} \mathrm{Sm}$, and chondritic reference values of ${ }^{147} \mathrm{Sm} /{ }^{144} \mathrm{Nd}=0.1967$ and ${ }^{143} \mathrm{Nd} /{ }^{144} \mathrm{Nd}=0.512638$, after Wasserburg et al. (1981). Uncertainty on $\varepsilon \mathrm{Nd}$ calculations is approximately $\pm 0.1 \varepsilon \mathrm{Nd}$ units, based on error propogation of $\pm 0.5 \%$ on the Sm/Nd ratio, and \pm 0.00002 for ${ }^{143} \mathrm{Nd} /{ }^{144} \mathrm{Nd}$, based on sample and standard reproducibility (see also analytical methods section)

${ }^{\text {a }}$ Sample UP51D is a duplicate analysis of UP 51, conducted as a completely separate dissolution

$\mathrm{Pb}$ zircon ages for the Merensky Reef, both from the Eastern Limb $(2056.88 \pm 0.41 \mathrm{Ma})$ and from the Western Limb $(2057.04 \pm 0.55 \mathrm{Ma}$; revised from Scoates and Friedman 2008) (Scoates and Wall 2015). These ages can be directly compared as the analyses were done in the same laboratory using the same pretreatment technique, analytical protocols, and data reduction. They are slightly older, however, and outside of analytical uncertainty, than the CA-TIMS U-Pb zircon age of $2055.40 \pm 0.30 / 0.44 / 6.0$ for a sample of the Merensky Reef (Eastern Limb) reported in Zeh et al. (2015). This difference can be attributed to a systematic bias between the two laboratories based on analysis of EARTHTIME synthetic solutions and use of different $U$ isotopic compositions. Our long-term result for the EARTHTIME $2 \mathrm{Ga}$ synthetic solution (ET-2Ga) yields a weighted mean ${ }^{207} \mathrm{~Pb} /{ }^{206} \mathrm{~Pb}$ age of $2000.11 \pm 0.27 / 0.27 / 6.0 \mathrm{Ma}$ (MSWD $=0.61, n=30$ ), which is identical within uncertainty with published values (Condon et al. 2008; Scoates and Wall 2015), whereas Zeh et al. (2015) report a younger weighted mean ${ }^{207} \mathrm{~Pb} /{ }^{206} \mathrm{~Pb}$ age of $1999.41 \pm 0.23 / 0.40 / 6.0 \mathrm{Ma}$. Zeh et al. (2015) also corrected the measured uranium isotopic ratios assuming ${ }^{238} \mathrm{U} /{ }^{235} \mathrm{U}=137.818 \pm 0.045$ (Hiess et al. 2012) compared to the more commonly used value of 137.88 in this study (e.g., Mattinson 2010; Schoene 2014); Adopting a value of ${ }^{238} \mathrm{U} /{ }^{235} \mathrm{U}=137.818$ decreases the ${ }^{207} \mathrm{~Pb} /{ }^{206} \mathrm{~Pb}$ age by approximately 850,000 years at ca. $2.05 \mathrm{Ga}$. Combined, these effects are significant enough to produce a 1-2 million year difference in ages measured in the different laboratories using the same mineral chronometer (zircon) from the same unit (Merensky Reef) analysed by the same technique (CA-TIMS, single grains) with EARTHTIME tracers and referenced to EARTHTIME synthetic solutions.

\section{Discussion}

\section{Summary of the crystallisation history of the Uitkomst intrusion}

Following the discovery of massive sulphide ore in 1990, the broad aspects of the crystallisation history of the Uitkomst intrusion were established in a number of publications (Gauert et al. 1995, 1996; Theart and de Nooy 2001; Li et al. 2002; Maier et al. 2004; Sarkar et al. 2008; Yudovskaya et al. 2015). Our data provide added detail, but are consistent with the general model summarised in the following: (i) Compositional heterogeneity in the lower portion of the intrusion, expressed by variability in mineral proportions and incompatible trace element contents (Figs. 6 and 7), is interpreted to reflect in situ contamination of the initial magma batches by dolomitic host rocks; (ii) The lack of whole rock and mineral fractionation in the central portion of the intrusion, reflected by $\mathrm{Mg \#}, \mathrm{MgO}$ and $\mathrm{Cr}$ contents (Fig. 7), is thought to result from continuous flux of unevolved magma through a magma conduit; (iii) Fractionation in the upper portion of the intrusion expressed by decreasing Mg\# and increasing incompatible trace element contents (Fig. 7), is interpreted to reflect crystallisation after flow of magma through the conduit had ceased. The peaks in $\mathrm{TiO}_{2}$ in the lower portion of the MGN, and in $\mathrm{P}_{2} \mathrm{O}_{5}$ in the centre of the MGN (Fig. 7), are interpreted to reflect the onset of magnetite and apatite saturation, whereas the strong depletions of $\mathrm{Rb}$ (and $\mathrm{K}_{2} \mathrm{O}$ ) at the top of the MGN may be due to leaching of these elements by hydrothermal fluids derived from the country rocks consistent with the heavy $\mathrm{O}$ isotope ratios of the rocks (Sarkar et al. 2008); (iv) Sharp reversals in $\mathrm{Zr}, \mathrm{Cr}$, and $\mathrm{MgO}$ at the base of 

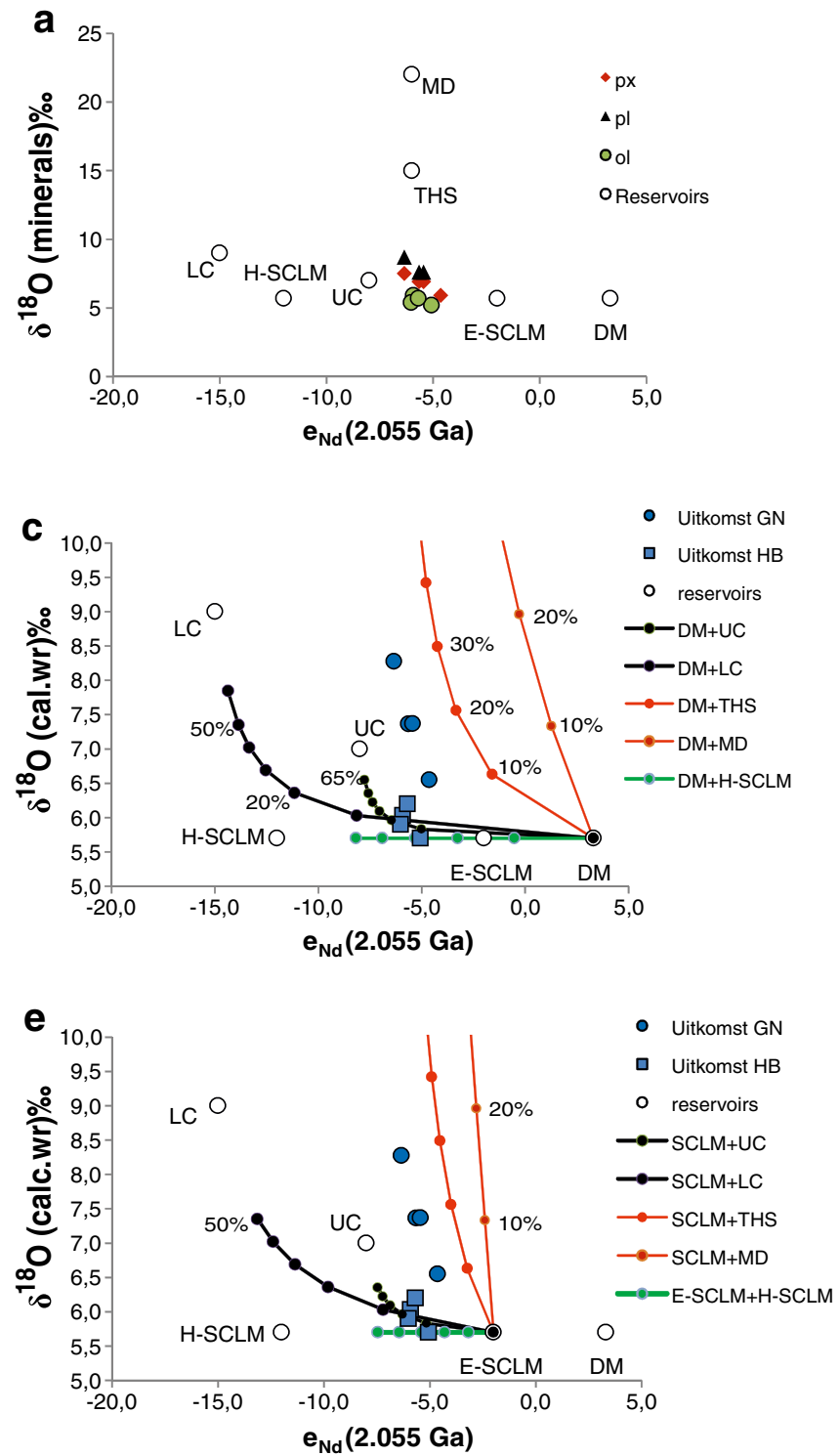

Fig. 9 a Isotopic compositional variation in $\mathrm{Nd}$ (this study) and $\mathrm{O}$ (Sarkar et al. 2008) for the Uitkomst Intrusion. Sample dots reflect Nd isotopes from whole rocks and $\mathrm{O}$ isotopes from minerals (Sarkar et al. 2008). b Mineral O isotope data have been recalculated to whole rocks, using procedure explained in Online Resource 3. c Modelling of Nd-O isotopic variation for Uitkomst samples using depleted mantle as mantle reservoir. Reservoirs labelled as in (a). GN = Gabbronorites and $\mathrm{HB}=$ Harzburgites. Mixing compositions are discussed in the text and shown in Table 3. The increments on the mixing curves are in $10 \%$ intervals. d Data of $\mathrm{c}$ plotted at a larger scale for the $\mathrm{y}$ axis.

the UGN (Fig. 7) are considered to reflect roof crystallisation of this unit.

\section{The age of the Uitkomst complex}

Previous authors have proposed that the Uitkomst Complex formed part of the Bushveld event (Gauert et al. 1995). Until recently, this model lacked conclusive isotopic support. De Waal et al. (2001) determined an age of $2044 \pm 8$ Ma for a
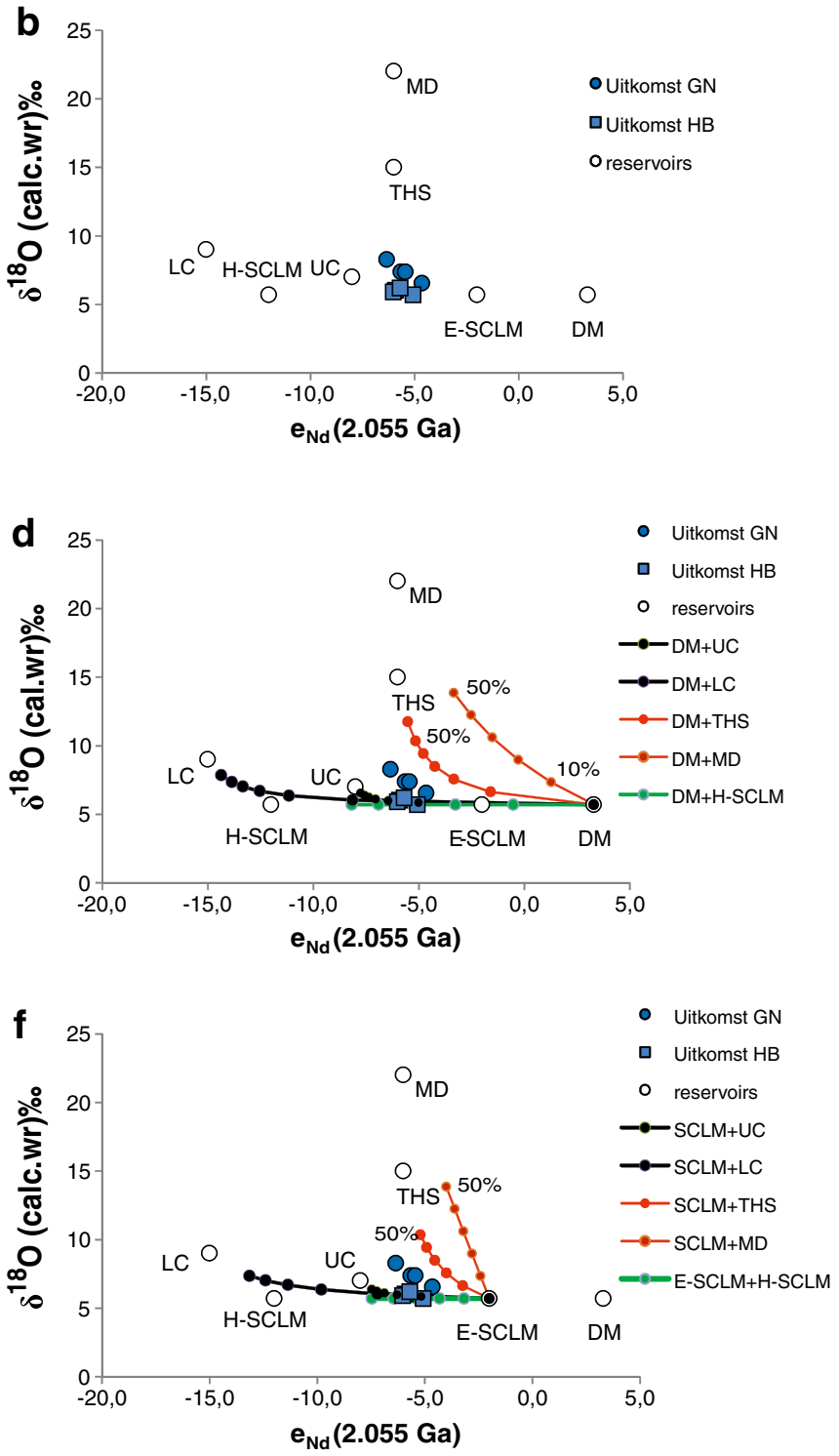

LC = Lower Crust; UC = Upper Crust; THS = Timeball Hill Shale; MD = Malmani Dolomite $;$ E-SCLM = Eclogitic Subcontinental Lithospheric Mantle; H-SCLM = Harzburgitic Subcontinental Lithospheric Mantle; DM = Depleted Mantle. e Modelling of Nd-O isotopic variation for Uitkomst samples using eclogitic SCLM as mantle reservoir. $\mathbf{f}$ Data of e plotted at a larger scale for the $y$ axis

diorite in the upper portion of the Complex (MGN). This led Rajeesh et al. (2013) to suggest that the Uitkomst Complex formed part of the last pulse of the Bushveld large igneous province. Subsequent work by Wabo et al. $(2054.5 \pm 6.9 \mathrm{Ma}$, 2015), likely also on material from the MGN, found a closer age overlap with the Bushveld Complex, but still lacked sufficient precision to be conclusive. The new age presented in this study $(2057.64 \pm 0.69 \mathrm{Ma})$ is nearly identical to the age of the Merensky Reef in both the eastern $(2056.88 \pm 0.41 \mathrm{Ma})$ 

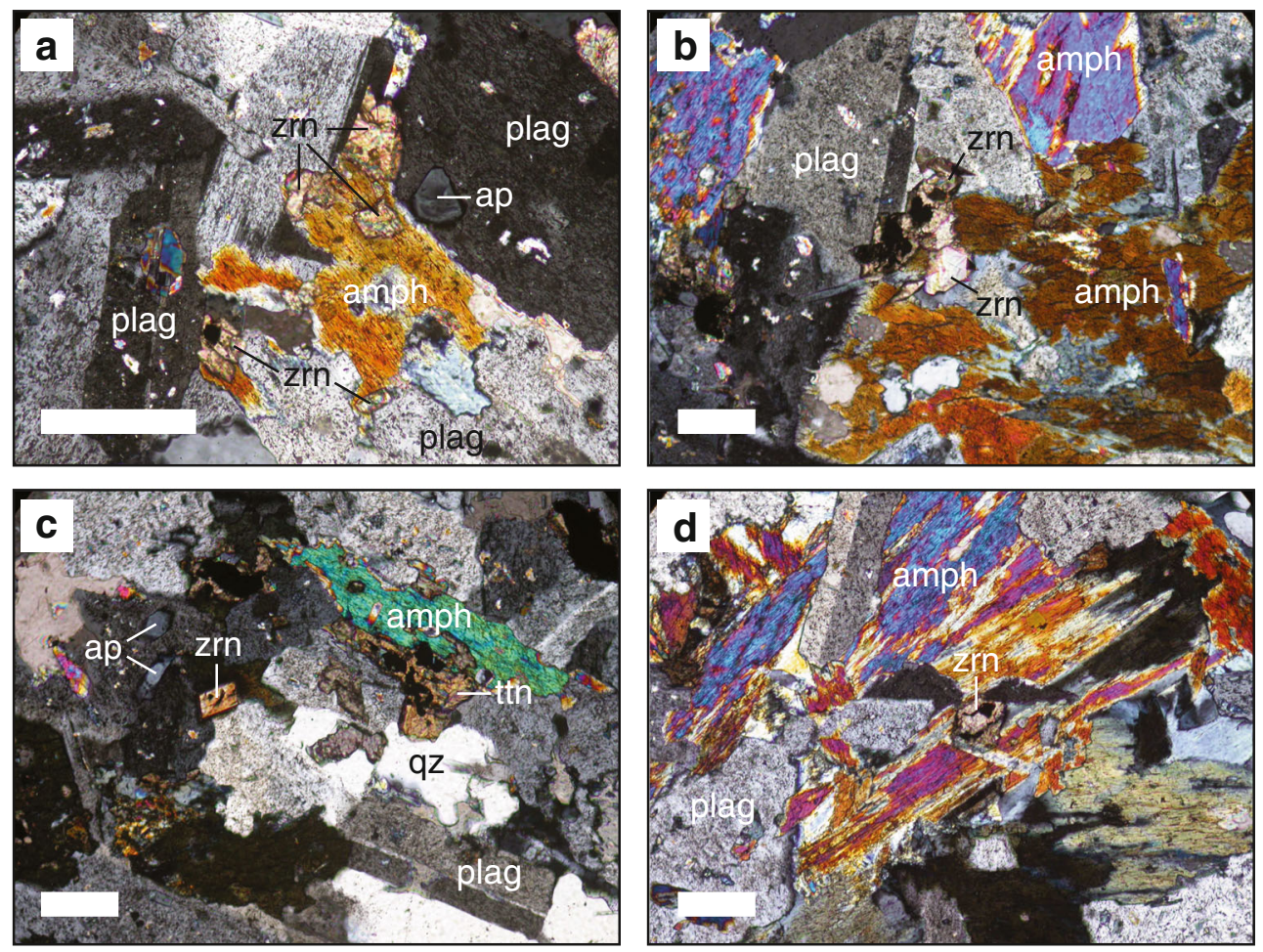

Fig. 10 Representative photomicrographs showing the morphology and textural setting of zircon in sample SH176/Up10 from the Uitkomst intrusion. All images are in cross-polarised light and the scale bar is $200 \mu \mathrm{m}$ long in each panel. a Abundant zircon along the margins and within amphibole adjacent to plagioclase. Note the presence of euhedral apatite and pervasive secondary sericite in plagioclase. b Euhedral zircon

and western limb $(2057.04 \pm 0.55 \mathrm{Ma})$ of the complex (Scoates and Wall 2015). This leaves little doubt that the Uitkomst and Bushveld intrusions formed part of the same igneous event.

\section{Constraints on parent magma composition}

Based on similarities between the composition of the Uitkomst chilled margins and the high-magnesian andesitic Bushveld B1 magmas, Gauert et al. (1995) and De Waal et al. (2001) suggested that the bulk of the Uitkomst intrusion crystallised from magma similar in composition to B1, whereas the basal and uppermost gabbroic chilled margins crystallised from a mildly alkaline tholeiite. This model is largely consistent with the data presented here. The rocks from the Uitkomst intrusion and the LZ and LCZ of the Bushveld Complex have similar $\varepsilon \mathrm{Nd}$ values and incompatible trace element patterns, including elevated LILE and LREE, high La/ $\mathrm{Yb}$ ratios, and negative $\mathrm{Nb}$, Ta and $\mathrm{Ti}$ anomalies. Uitkomst cumulates are more enriched in all incompatible trace elements, but this can be explained by higher trapped melt contents, consistent with petrographic observations. The Uitkomst chilled margins and the Bushveld B1 magma also show strong similarity in terms of trace element signature, grains along margin of amphibole in contact with plagioclase. $\mathbf{c}$ Euhedral zircon and apatite with plagioclase, quartz, and amphibole. Note the presence of titanite along the amphibole grain margin. d Euhedral zircon associated with amphibole and plagioclase. Mineral abbreviations: $\mathrm{zrn}=$ zircon, ap = apatite, plag = plagioclase, amph = amphibole, $\mathrm{qz}=$ quartz, $\mathrm{ttn}=$ titanite

except for the lack of a negative Ti anomaly in the Uitkomst basal chilled margin, previously observed by De Waal et al. (2001). Together with the overlap in age between the two intrusions, this strongly suggests that the Uitkomst intrusion formed part of the Bushveld magmatic event. The data further suggest that the Uitkomst intrusion crystallised exclusively from Bushveld B1 magma, with no evidence for influx of Bushveld B2 or B3 magmas.

\section{Magma source and crustal contamination}

The nature of the mantle source to the magmas of the Bushveld event, including the Uitkomst intrusion, remains controversial. Past authors have advocated either the subcontinental lithospheric mantle (SCLM) and/or the asthenosphere (Harmer and Sharpe 1985; Maier et al. 2000; Maier and Barnes 2004; Richardson and Shirey 2009; Barnes et al. 2010; Wilson 2012; Yudovskaya et al. 2015; Maier et al. 2016).

The Uitkomst intrusion data are modelled here in terms of prospective mixtures of mantle-derived magma (either a LREE-depleted asthenospheric mantle or an enriched, source-contaminated mantle) and Meso- to Neoarchaean crust consistent with the host rocks to the intrusion (Fig. 9). The 
modelling has been constrained to provide minimum amounts of crustal contamination, such that possible contaminants can be ruled out or prioritised. Lower crustal compositions are represented by ca. 3.5 Ga old crustal basement consistent with proximal greenstone terrains such as Barberton, giving a timecorrected $\varepsilon \mathrm{Nd}$ of around -15 by ca. $2.05 \mathrm{Ga}$. The $\delta^{18} \mathrm{O}$ composition is based on the isotopic composition of ca. $3.2 \mathrm{Ga}$ Vredefort Archaean basement rocks and Archaean granites underlying the western Bushveld Complex with $\delta^{18} \mathrm{O}$ of about +9\%o (Harris et al. 2005). Upper crustal compositions are based on ca. 2.7 Ga granitic as well as volcanic rocks such as the lavas of the Dullstroom and Rooiberg formations, with time-corrected $\varepsilon \mathrm{Nd}$ of around -8 (Buchanan et al. 2004) and $\delta^{18} \mathrm{O}$ of around $+7 \%$ (Harris et al. 2005), providing a relatively juvenile and immature signature to contrast with proposed lower crust for modelling purposes. The Timeball Hill Shale and Malmani Dolomite $\delta^{18} \mathrm{O}$ of approximately +15 and $+22 \%$ o, respectively, are from Harris and Chaumba (2001), whereas $\varepsilon \mathrm{Nd}$ of about -6 have been assigned on the basis of a ca. 2.6 Ga age for these Pretoria Group sedimentary rocks. This should be treated as a maximum $\varepsilon \mathrm{Nd}$ value, given that the shales, in particular, may have an older provenance and hence older Nd model ages.

Prospective sources for the mafic melts include the depleted mantle (DM), for which a $\varepsilon \mathrm{Nd}$ of +3.3 can be calculated for the progressively depleting mantle of DePaolo (1981), and a typical primary igneous mantle $\delta^{18} \mathrm{O}$ of $+5.6 \%$ (Kyser 1986) has been assigned. The subcontinental lithospheric mantle contains a wide range of isotopic compositions and ages, as manifested in the Kaapvaal subcratonic signatures recorded in silicate inclusions within kimberlite-hosted diamonds (Richardson et al. 1984; MacGregor and Manton 1986; Richardson and Shirey 2008). Richardson and Shirey (2008) identified isotopically distinct reservoirs of eclogitic subcontinental lithospheric mantle (or E-SCLM) and its harzburgitic complement (H-SCLM), where $\varepsilon N d$ values at 2050 Ma calculated from the lherzoltic clinopyroxene data of Richardson et al. (1993) were between -1.7 and -6.7 , whereas H-SCLM ranges between -12 to -13 , based on garnet inclusion composites from Finsch and Kimberley diamonds (Richardson et al. 1984).

The oxygen isotopic composition of SCLM is expected to vary between normal peridotitic mantle $\delta^{18} \mathrm{O}$ values of about $+5.6 \%$, and a more heterogeneous range of +2.3 to $+7.3 \%$ in minerals in eclogitic xenoliths, linked to variable contributions from subducted oceanic crust (MacGregor and Manton 1986; Lowry et al. 1999). SCLM is thus somewhat complex to robustly constrain as a mixing end-member. The isotopic composition is relatively heterogeneous because H-SCLM is characterised by evolved $\mathrm{Sr}$ and $\mathrm{Nd}$ isotopic compositions (Richardson and Shirey 2008), but normal mantle oxygen isotopic compositions (Valley et al. 1998). In contrast, the E-SCLM has relatively primitive $\mathrm{Sr}$ and $\mathrm{Nd}$, but has more evolved and more heterogeneous $\mathrm{O}$ 


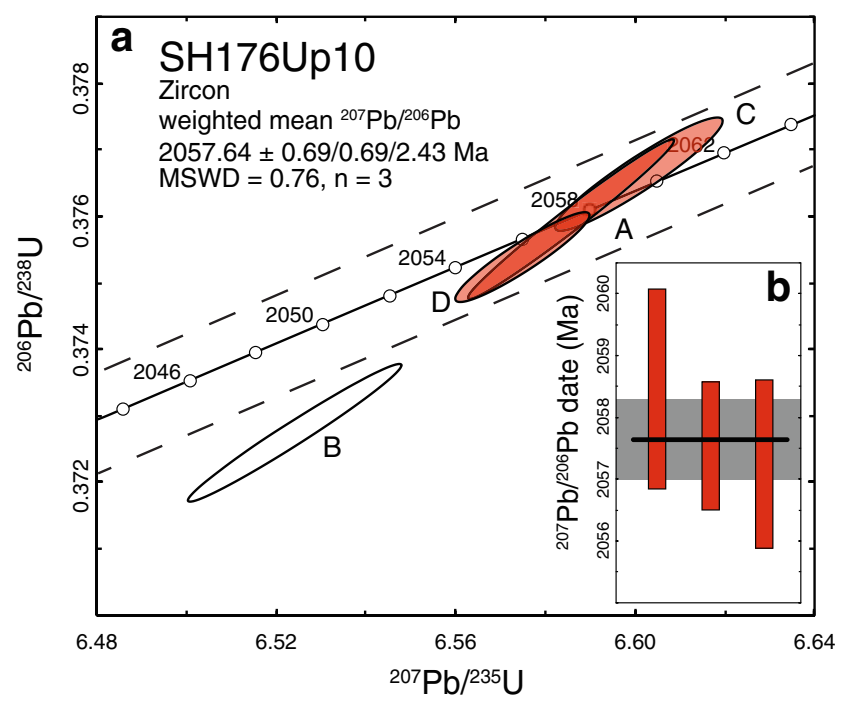

Fig. 11 a Concordia diagram showing U-Pb geochronological CA-IDTIMS results for chemically abraded zircon for sample SH176/Up1 in the Uitkomst intrusion. The calculated weighted mean ${ }^{207} \mathrm{~Pb} /{ }^{206} \mathrm{~Pb}$ age is indicated where the uncertainty is reported in the $\pm \mathrm{X} / \mathrm{Y} / \mathrm{Z}$ format with internal error in the absence of all systematic errors $( \pm X)$, including tracer calibration error $( \pm \mathrm{Y})$, and including uncertainty due to decay-constant errors $( \pm Z$ ). MSWD refers to the mean square of the weighted deviates. The concordia curve is shown as the solid black line with ages indicated in millions of years (Ma); dashed lines show the error bounds of the concordia curve due to uncertainty in the decay constants of U. Each ellipse indicates the analysis of a single zircon grain and the unfilled ellipse indicates the result not included in the weighted mean age. b Bar diagram where each bar represents the analysis of each single zircon crystal; the horizontal black line indicates the weighted mean ${ }^{207} \mathrm{~Pb} /{ }^{206} \mathrm{~Pb}$ date, the dark grey band includes represents the internal reproducibility

(Valley et al. 1998) and Os (Richardson and Shirey 2008) isotopic compositions.

Regarding elemental concentrations for the contamination modelling, the mass balance of $\mathrm{O}$ is effectively equal between all contributing components such that the mixing of isotopically-distinct end-members can ignore this factor. This is not the case for the REE, where Nd concentrations used for modelling end member compositions vary from about $2 \mathrm{ppm}$ in the depleted mantle, based on abundances in komatiites (Lahaye et al. 1995), around 6 ppm in subcontinental lithospheric mantle (Richardson et al. 1984; Richardson et al. 1993), 30-100 ppm in relatively undifferentiated lower crustal granites (e.g., Schoene et al. 2009), and 50 ppm in Proterozoic upper crustal rocks, based on concentrations in the Rooiberg Group (Buchanan et al. 2004).

The Uitkomst data can be best explained by a mixture of isotopically heavy oxygen from Transvaal Supergroup sedimentary rocks plus radiogenic $\mathrm{Nd}$ from older lithosphere. Table 3 summarises the results of mixing calculations in terms of end member compositions and mixing proportions. What is evident from Table 3 and from Fig. 9b, c is that it is not possible to reconcile the isotopic compositions of both oxygen and neodymium by mixing a mantle-derived magma with any one crustal reservoir. Mixing of melt derived from either depleted mantle or eclogitic sub-continental mantle lithosphere with either ancient or juvenile crust, or with harzburgitic SCLM can account for the Nd isotopic compositional variation, but no amount of contamination from these reservoirs can account for the variation in oxygen isotopic compositions, for which small amounts $(<30 \%)$ of Neoarchaean and Proterozoic sedimentary rocks hosting the intrusion would be required. Similarly, these same sediments cannot explain the Nd isotopic compositional range present in the Uitkomst suite, but for which assimilation of Archean or Proterozoic crust or harzburgitic SCLM yield values compatible with the Uitkomst composition.

The presence of several contaminants complicates establishment of relative importance of different contaminants. However, comparison between Bushveld and Uitkomst provides some clues. Maier et al. (2016) identified a komatiitic quenched rock in a chilled margin sequence of the Western Bushveld and proposed that the Bushveld B1 magmas were derived largely from the asthenosphere, followed by variable amounts of contamination with upper crust. As Uitkomst and Bushveld show good overlap in $\varepsilon \mathrm{Nd}$ and incompatible trace element ratios, we argue that the Uitkomst magma is equally derived from the asthenosphere, followed by contamination with sub-Transvaal Supergroup crustal rocks.

The simplest scenario, consistent with the $\mathrm{Nd}$ and $\mathrm{O}$ isotopic compositional variation, involves interaction at depth between depleted mantle (asthenosphere) melts with either 5\% lower or $\sim 20 \%$ upper crust. Because the trace element patterns of the Uitkomst and Bushveld cumulates show good overlap with upper crust (Maier et al. 2000; Barnes et al. 2010; Maier et al. 2016) the latter model is favoured here. Additional contamination of the magnesian andesitic parent melt by a small amount $(<5-15 \%)$ of roof- or wall-sedimentary rocks occurred during final emplacement.

The low $\delta^{18} \mathrm{O}$ values of the Uitkomst harzburgites are difficult to explain by contamination with normal mantle material (Fig. 9), suggesting that a contribution from both harzburgitic SCLM and isotopically light oxygen which has been identified from eclogitic sources, likely a by-product of seawater metasomatism, (Valley et al. 1998) may be required. As most Bushveld rocks have higher $\delta^{18} \mathrm{O}$ than the bulk of the Uitkomst intrusion, the former must have assimilated more Transvaal sedimentary rocks with high $\delta^{18} \mathrm{O}$ than Uitkomst. Possibly, contaminated magma in the lower portion of the Uitkomst intrusion could have been flushed out of the conduit by relatively uncontaminated magma pulses.

The similarity in trace element patterns between Uitkomst and Bushveld cumulates indicates that the enhanced $\mathrm{O}$ contamination of the Bushveld was not accompanied by significant trace element addition, from which we deduce that $\mathrm{O}$ transfer occurred largely by a relatively trace element-poor 


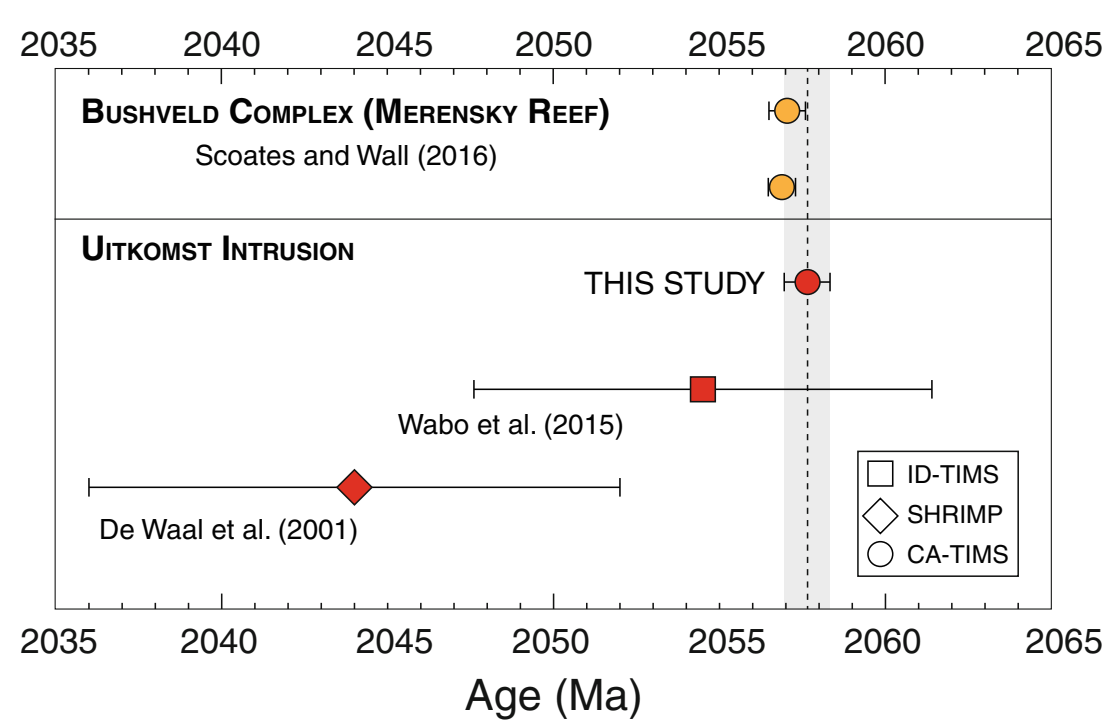

Fig. 12 Summary of U-Pb results from this study compared to select ages for rocks from the Uitkomst intrusion and from the Merensky Reef in the Upper Critical Zone of the Bushveld Complex. The vertical dashed line and grey band indicate the CA-TIMS age and associated uncertainty determined from this study and is considered the crystallisation age of the quartz monzodiorite from the Upper Gabbronorite unit of the Uitkomst intrusion. Symbols for previously published ages are according to the analytical technique. Sources: Merensky Reef (Scoates and Wall 2015), Uitkomst intrusion (De Waal et al. 2001; Wabo et al. 2015)

erosive deepening of an originally sill-like intrusion formed when a SW-NE trending dyke intersected subhorizontal lithological boundaries in the Transvaal Supergroup, somewhat analogous to the model of Saumur et al. (2015) proposed for the Discovery Hill deposit, Voisey's Bay. In the case of Uitkomst, we envisage that the parent magma to the LP was injected concurrently with the initial stages of injected along the contact between the Malmani dolomite and the Bevets conglomerate. In addition to assimilation of the roof rocks, the magma caused devolatisation of the floor dolomite, as well as partial melting facilitated by the presence of $\mathrm{H}_{2} \mathrm{O}$ possibly derived from pelitic interlayers (Wyllie and Tuttle 1960). Slurries of silicate and chromite crystals, together with droplets of sulphide liquid, slumped into the developing troughs which constituted efficient hydrodynamic traps. Locally, the slurry injected in a sill-like manner into the floor and sidewalls of troughs. Ongoing devolatisation of the dolomitic floor during accumulation of the crystal mush caused syn-magmatic subsidence resulting in the trough-like shape of the intrusion.

Significant dolomite devolatisation is suggested by several lines of evidence. Firstly, mineralogical studies showed that xenoliths in the LP are calcsilicates consisting dominantly of calcite, pyroxene and tremolite, with minor diopside, augite, forsterite, monticellite, brucite, spinel, periclase, wollastonite, epidote and apatite (Hulley 2005). Secondly, the abundance of clinopyroxene, and the presence of larnite in CIPW norms from the LP suggests that melting and/or dissolution of dolomite likely also occurred (Fig. 6, Online Resources 1). model involves localised inflation, roof stoping and 


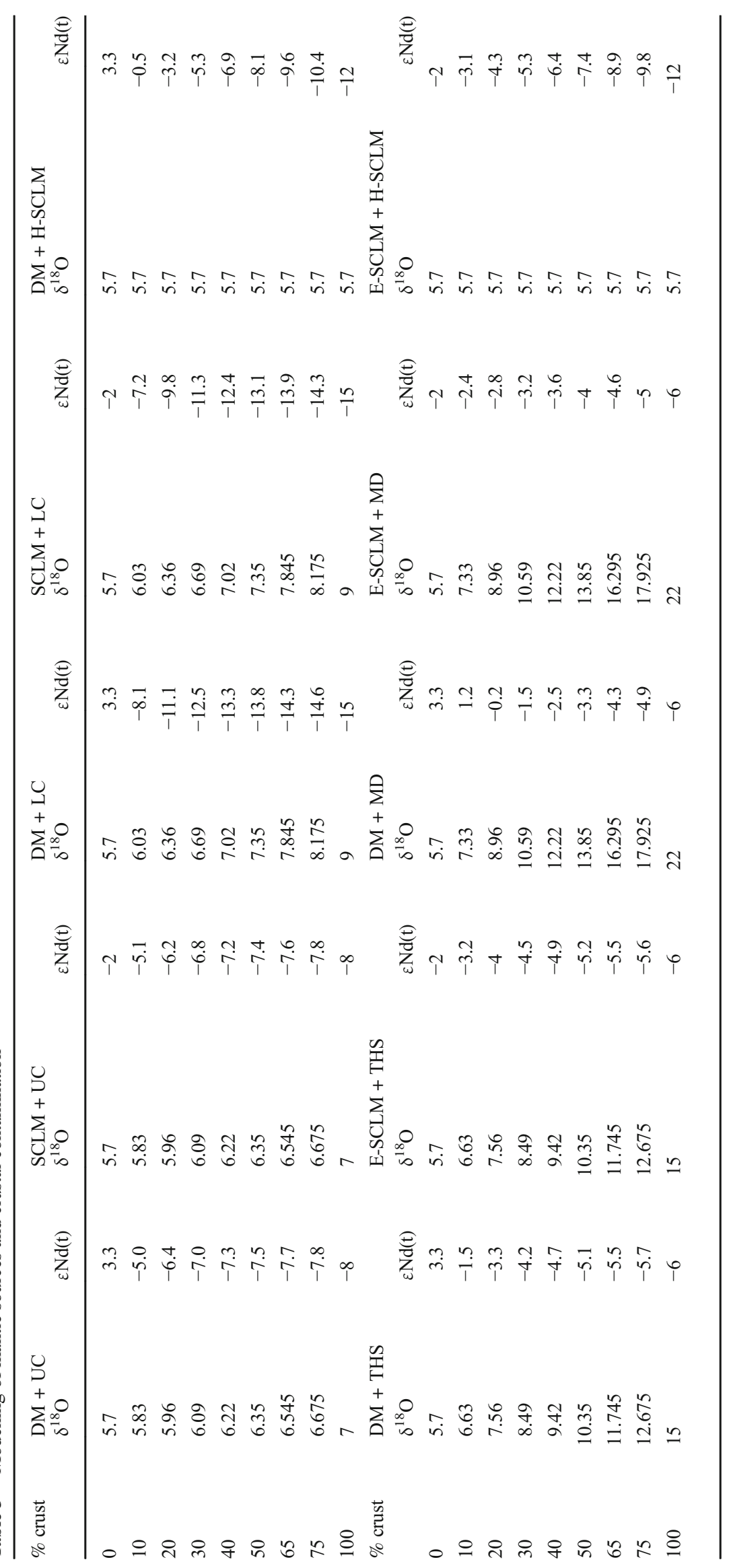


Thirdly, large-scale transfer of $\mathrm{CO}_{2}$ into the magma would be consistent with the unusually forsteritic composition of Uitkomst olivines, compared to most other Bushveld cumulates, if it is accepted that $\mathrm{CO}_{2}$ contamination leads to oxida-

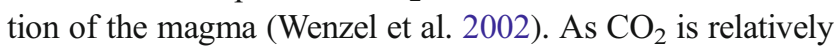
insoluble in silicate magma (Lesher and Spera 2015) we envisage that much of the $\mathrm{CO}_{2}$ would have passed through the chamber into the roof. Finding direct evidence for this model will require detailed mineral chemical and fluid inclusion studies; for example, interaction between $\mathrm{CO}_{2}$ and the magma may have resulted in $\mathrm{CO}_{2}$ rich fluid inclusions or high $\mathrm{CO}_{2}$ contents in hydrous silicates.

Additional evidence for interaction of dolomite with the Uitkomst magma is provided by $\mathrm{O}$ isotopes. Calcsilicate xenoliths in the LP have $\delta^{18} \mathrm{O}$ values of +14 (Hulley 2005), significantly lower than typical Transvaal dolomite $\left(\delta^{18} \mathrm{O} 20-24\right.$; Swart 1999). This is likely the result of silica addition from the magma. Hulley (2005) also found that within $1.5 \mathrm{~m}$ of a calcsilicate xenolith, $\delta^{18} \mathrm{O}$ is $7.3-8.9 \%$, significantly higher than in the overlying ultramafic rocks which have $\delta^{18} \mathrm{O}$ mostly around +5.5 to $+6 \%$ o (Sarkar et al. 2008). However, the O contamination is only apparent in a relatively narrow contact zone surrounding the xenoliths, interpreted to reflect the dynamic nature of the Uitkomst magma conduit in which contaminated magma was flushed out of the conduit by uncontaminated magma. As dolomite is relatively depleted in most incompatible trace elements (Klein and Beukes 1989), the contamination is not recorded by incompatible trace element ratios.

The detailed mechanism of S contamination remains unresolved. The mineralized Uitkomst peridotites have nonmagmatic $\mathrm{S}$ isotope signatures $\delta^{34} \mathrm{~S}-8$ to $-2 \%$ o (Gauert et al. 1996; Li et al. 2001; Sarkar et al. 2008), overlapping with both the host Malmani dolomites -10 to $+10 \%$, Cameron 1982) and the Timeball Hill shale $(-12$ to -18 , data derived from western portion of Transvaal Supergroup). Gauert et al (1996). favoured the dolomite as the $\mathrm{S}$ source, partly because their shale samples were very $\mathrm{S}$ poor. However, it is possible that their samples lost $\mathrm{S}$ during contact metamorphism. Data on Transvaal Supergroup rocks from the Northern Cape indicates that the dolomite has an order of magnitude less $\mathrm{S}(0.4 \%)$ than the shales (4\% on average, Klein and Beukes 1989). To us, this suggests that the Uitkomst magma reached sulphide saturation in response to $\mathrm{S}$ assimilation largely from the Timeball Hill shale. However, some additional S addition from the Malmani dolomite, during downward percolation into the dolomite, is possible, if not likely.

\section{Interpretation of chalcophile metal data}

The concentration of chalcophile metals and $\mathrm{S}$ is relatively high ( $>500 \mathrm{ppb}$ PGE, $>10,000 \mathrm{ppm} \mathrm{S}$ ) in the lowermost $250 \mathrm{~m}$ of the intrusion, within the BG, LP, CH and the basal $100 \mathrm{~m}$ of the MH (Maier et al. 2004). Most of the remainder of the MH has $<<1000$ ppm S and likely crystallised from S undersaturated magma. Notably, despite of the precipitation of significant amounts of sulphides in the lower part of the intrusion, $\mathrm{Cu} / \mathrm{Pd}$ remains at or below primitive mantle level throughout the $\mathrm{MH}$, consistent with continued magma replenishment.

After the crystallisation of sulphide-poor rocks in the upper $\mathrm{MH}$ and the basal PX, sulphide saturation was again reached mid-level within the PX, forming an approximately $15 \mathrm{~m}$ wide horizon of PGE enrichment with between 50 and $150 \mathrm{ppb} \mathrm{Pt}+\mathrm{Pd}+\mathrm{Au}$ (Roberts et al. 2015), and resulting in a sharp increase in $\mathrm{Cu} / \mathrm{Pd}$ in the overlying rocks of the MGN. In the UGN, $\mathrm{Cu} / \mathrm{Pd}$ reverts to primitive mantle levels. This unit is thus clearly not related to the underlying rocks by fractionation, but may have formed from a new magma pulse or via roof crystallisation of an early stage magma undepleted in metals (Gauert 1998).

Those sulphide-rich rocks in the lower portion of the intrusion which, based on their relatively homogenous $\mathrm{Cu} / \mathrm{Ni}$ ratios, are unlikely to have undergone significant fractionation of monosulfide solid solution (mss) have average metal tenors (on a $100 \%$ sulphide base) of $2.2 \% \mathrm{Cu}$, $4.7 \% \mathrm{Ni}, 7 \mathrm{ppm} \mathrm{Pt}$ and $10 \mathrm{ppm} \mathrm{Pd}$. Their Pt/Pd is 0.7, in sharp contrast to the internal Bushveld PGE reefs (Merensky Reef, UG2 chromitite) which have Pt/Pd significantly above unity (Maier et al. 2013), but resembling the lower portions of the Platreef that have $\mathrm{Pt} / \mathrm{Pd}<1$ (Kinnaird 2005). Barnes et al. (1997) have shown that certain sulphide deposits have lower $\mathrm{Pt} / \mathrm{Pd}$ than their parent magmas and suggested that this is due to higher $\mathrm{D}_{\mathrm{Pd}}$ than $\mathrm{D}_{\mathrm{Pt}}$ into sulphide liquid. Based on this argument, one could propose that the relatively low $\mathrm{Pt} / \mathrm{Pd}$ at Uitkomst is a result of the relative sulphide enrichment of the intrusion. However, in view of the most recent estimates of $\mathrm{D}$ values between sulphide and silicate melt $\left(10^{7}-10^{8}\right.$ for Pt and Pd, respectively; Fonseca et al. 2009) this model now seems implausible because at such high $\mathrm{D}$, the metal ratio in the sulphide melt should be similar to that in the parent silicate magma, irrespective of $\mathrm{R}$ factor. Thus, the PGE data suggest that the magma from which the sulphides precipitated had lower PGE contents and $\mathrm{Pt} / \mathrm{Pd}$ ratios than the Bushveld B1 magma. The best fit with the observed metal contents is achieved by assuming approximately $9 \mathrm{ppb} \mathrm{Pt}$ and $12 \mathrm{ppb}$ $\mathrm{Pd}$ in the Uitkomst magma, in contrast to an average of 15 ppb Pd and 19 ppb Pt in Bushveld B1 magma (Barnes et al. 2010).

Ertel et al. (1999) have shown that Pt solubility in basalt is far lower than that of Pd, particularly at relatively reduced conditions. Maier et al. (2015) have presented an example of highly Pt enriched orthopyroxene cumulates, at Monts de Cristal in Gabon, interpreted to result from precipitation of $\mathrm{Pt}$ arsenides. This could suggest that the 
Uitkomst magma fractionated Pt-rich phases prior to and during emplacement, either during ascent through the lithosphere or lateral flow within the Uitkomst chonolith. This model is consistent with the relative $\mathrm{Pt}$ enrichment of the uppermost $\mathrm{MH}$ and lowermost PX samples (up to $90 \mathrm{ppb}$ $\mathrm{Pt}, 4-6 \mathrm{ppb} \mathrm{Pd}$ ), possibly indicating that at that stage the magma was saturated in a Pt phase. We suggest that dolomite devolatisation led to magma oxidation (Wenzel et al. 2002) triggering enhanced chromite precipitation which, in turn, led to crystallisation of $\mathrm{Pt}$ phases in locally reducing conditions within the boundary layer between chromite crystals and the magma (Finnigan et al. 2008). The model is supported by the observation that the sample with the highest $\mathrm{Pt}$ content and $\mathrm{Pt} / \mathrm{Pd}$ ratio is a chromite-rich rock from the $\mathrm{CH}$.

\section{Origin of the $\mathrm{Ni}-\mathrm{Cu}$ and $\mathrm{Cr}$ ores}

The location of the Ni-Cu-PGE sulphide- and chromite ores in the centre of the lower trough of the Uitkomst chonolith suggests that ore formation is closely linked to the formation of the trough. Based on the observations documented here, we propose the following ore forming model (Fig. 13):

(i) The initial magma pulse intruded as a sill along the base of the Malmani dolomite, forming the basal gabbro (von Scheibler et al. 1995). The magma was relatively differentiated $(\sim 5 \% \mathrm{MgO}, \mathrm{Cu} / \mathrm{Ni}>1,<10 \mathrm{ppb}$ PGE, see sample SH176-60, Online Resource 1), but had a broadly similar trace element signature as Bushveld B1 magma (Fig. 8). It precipitated relatively $\mathrm{Cu}$-rich disseminated sulphides forming the Basal Mineralised Zone (cf Fig. 1d). The S isotope data suggest that the $\mathrm{S}$ is largely derived from the mantle;

(ii) The first pulses of Mg-basaltic Uitkomst magma intruded near the top of the Malmani dolomite, possibly along the contact with the Bevets conglomerate;

(iii) The dolomitic floor rocks were progressively heated by magma flowing through the conduit and began to devolatize, emitting large quantities of $\mathrm{CO}_{2}$. The $\mathrm{CO}_{2}$ oxidised the magma causing high Fo contents in crystallising olivine. Due to its low solubility in basalt, much of the $\mathrm{CO}_{2}$ migrated through the magma chamber and into the roof rocks. In addition, much of the contaminated silicate magma was flushed out of the conduit by new batches of less contaminated magma;

(iv) In addition to dolomite, the magma likely also assimilated pelitic material of the Timeball Hill Shale, as suggested by the occurrence of shale xenoliths in the MH (Yudovskaya et al. 2015). Based on the S budget of the shales and dolomites (Cameron 1982), most of the external $\mathrm{S}$ assimilated by the Uitkomst magma was likely derived from the shale. The homogeneity of B1-like trace element signatures throughout the intrusion could be explained by arguing that the contaminated magma was flushed out of the conduit after sulphide melt had fractionated and accumulated at the floor of the chamber;

(v) Continued devolatisation led to significant volume reduction of the dolomite (Ganino et al. 2008). In addition, dolomite fragments likely spalled into the flowing magma (Barnes et al. 2015). The combination of these factors led to progressive downward erosion of the Uitkomst magma conduit;

(vi) Chromite precipitated at the top of the cumulate pile, triggered by magma oxidation in response to dolomite devolatisation and $\mathrm{CO}_{2}$ release (Hornsey 1999; Wenzel et al. 2002) and/or mixing of unevolved and evolved magma (Murck and Campbell 1986). Concentration of chromite into a massive layer several metres in thickness requires a highly efficient hydrodynamic sorting process, for example by means of slumping of chromitebearing slurries into the deepening lower trough. Mobilisation of the slurries was possibly facilitated by high $\mathrm{CO}_{2}$ bubble contents leading to sharply reduced viscosities of the flowing magma (Lesher and Spera 2015). Locally, the chromitite layer disintegrated during slumping, forming a multitude of schlieren;

(vii) The sulphide melt, and possibly some peridotite crystal mush at the base of the sill injected downwards into the devolatizing dolomite. In places, the magma eroded the basal gabbro. Some of the sulphide melt continued to percolate into the quartzitic floor rocks where it formed massive sulphide lenses;

(viii) Ongoing devolatisation of the dolomite led to sagging of the overlying cumulates into the centre of the lower trough, consistent with the presence of shale xenoliths in portions of the $\mathrm{MH}$ that are now located up to $100 \mathrm{~m}$ below the stratigraphic level of the lowermost Timeball Hill shale (Yudovskaya et al. 2015).

\section{Implications for magmatic ore formation in other mafic-ultramafic intrusions}

Several important magmatic ore deposits are associated with carbonaceous rocks, such as the Platreef/Flatreef of the Bushveld Complex (McDonald and Holwell 2011), the Noril'sk I (Naldrett and Li 2009), Jinchuan (Lehmann et al. 2007), and Aguablanca Ni-Cu sulphide deposits (Piña et al. 2009), and the Panzihua magnetite deposit in China (Ganino et al. 2008). We propose that in all these cases, devolatisation of floor carbonate played an important, and possibly critical role in ore formation. Devolatisation of the floor likely 


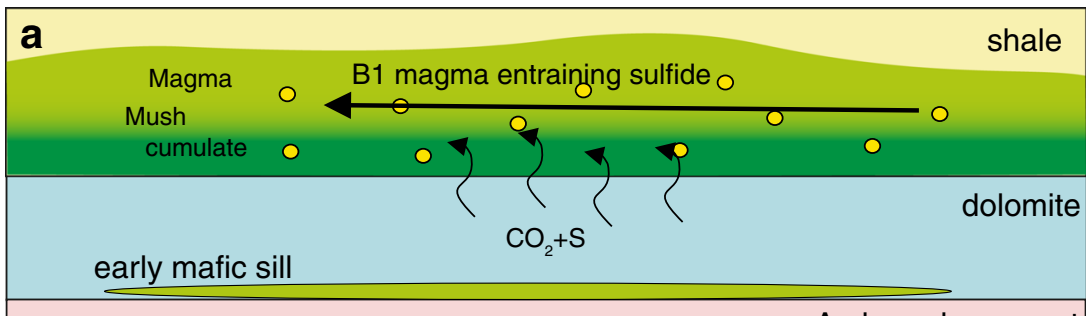

Archean basement
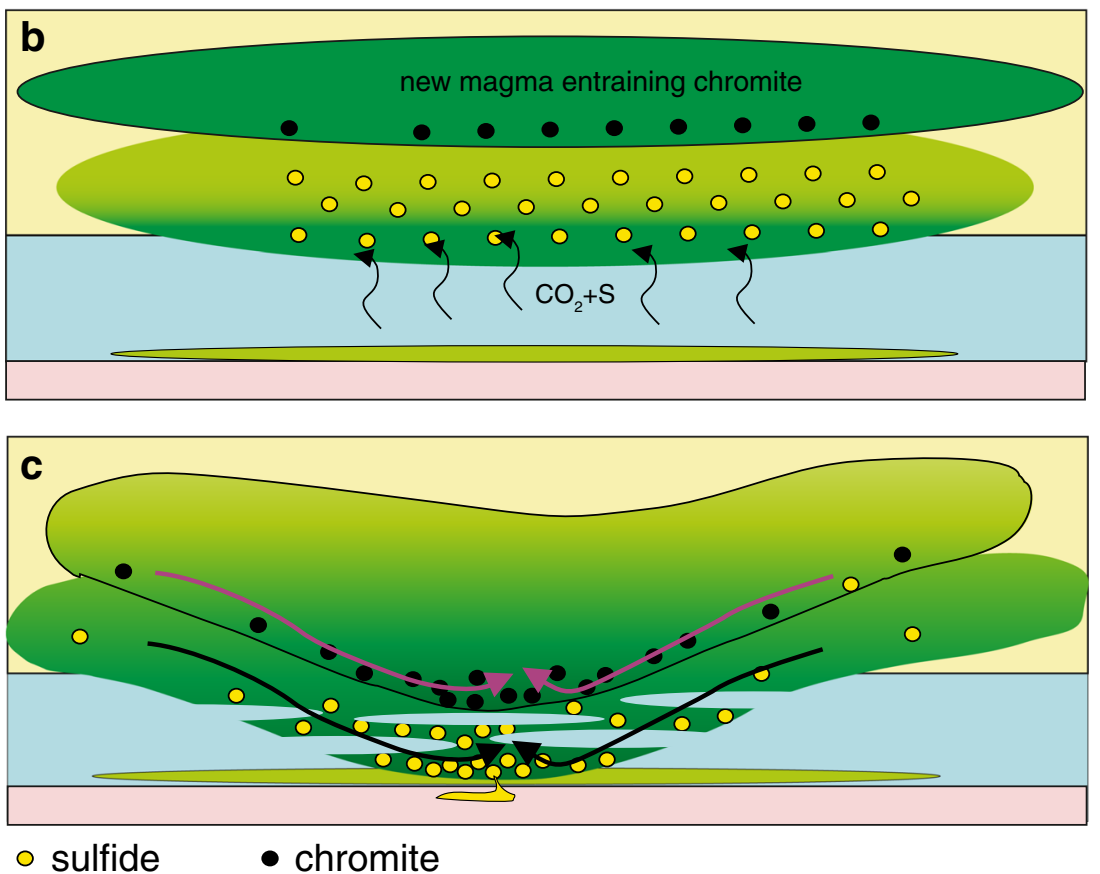

Fig. 13 Schematic model illustrating proposed formation of sulphide and chromite ores. a Long section, showing intrusion of early BG sill near basal contact of dolomite, followed by initial B1 magma pulse intruding near base of Timeball Hill Shale. Assimilation of external S from the shale triggers sulphide melt saturation in the magma. The sulphides are entrained by the flowing magma. The dolomitic floor rocks are heated and undergo devolatization of $\mathrm{CO}_{2}$. b Cross-section, showing continued devolatization of dolomite causing progressive injection of the intrusion into the floor. New magma pulses lead to inflation of sill. Migration of

resulted in relatively high concentrations of $\mathrm{CO}_{2}$ bubbles in the incompletely solidified cumulates and slumping of sulphide and oxide bearing crystal mushes into the developing troughs, resulting in hydrodynamic density sorting of the slurries and the formation of the sulfide- and oxide-rich horizons (Maier et al. 2013).

\section{Conclusion}

(i) U-Pb geochronology on zircon from the Main Gabbronorite Unit indicates that the Uitkomst intrusion $(2057.64 \pm 0.69 \mathrm{Ma})$ is coeval to the Merensky Reef of the Bushveld Complex, suggesting that the two intrusions form part of the same magmatic event.
$\mathrm{CO}_{2}$ through the cumulates and into the magma chamber triggers magma oxidation and chromite supersaturation. c Cross-section, showing further devolatization of dolomite, as well as magmatic erosion, removing a significant portion of the floor rocks, and causing slumping of sulfidic and chromite crystal slurries towards the centre of the trough, and into the partially eroded dolomite. This caused the formation of a thick chomitite layer in the trough, and numerous chromitite schlieren

(ii) The cumulates of the Uitkomst intrusion have trace element patterns and $\mathrm{Nd}$ isotope ratios closely resembling those of the Lower and Lower Critical Zones of the Bushveld Complex. This is considered to reflect a broadly similar melting and crustal contamination history, involving first partial melting of asthenosphere, followed by $\sim 20 \%$ contamination with sub-Transvaal Supergroup upper crust, and then variable amounts (5-20\%) of fluiddriven $\mathrm{O}$ contamination by Transvaal sedimentary rocks.

(iii) Sulphur isotope data indicate an important component of crustally derived sulphides in the lower ultramafic portion of the Uitkomst intrusion, likely derived from the Timeball Hill shale of the Transvaal Supergroup. Relatively low PGE tenors of the sulphide ores (mostly $\sim 20 \mathrm{ppm})$ suggest moderate $\mathrm{R}$ factors $(\sim 800)$ and thus relatively proximal derivation of the $\mathrm{S}$. 
(iv) $\mathrm{The} \mathrm{Pt} / \mathrm{Pd}$ of the sulphides is markedly lower than in most Bushveld reefs, suggesting that the Uitkomst magma lost Pt prior to final emplacement, possibly by crystallisation of Pt minerals precipitated on chromite, triggered by dolomite contamination and magma oxidation.

(v) Concentration of sulphides and chromite to form the ore deposits was controlled by progressive devolatisation of the dolomitic floor rocks of the intrusion, percolation of sulfidic crystal slurries into the floor, and sorting of sulfidic and chromitic slurries during slumping into the developing trough. Massive sulphide lenses located below the intrusion formed by downward percolation of sulphide melt.

(vi) Intrusion of mafic magma into carbonate rocks is considered to represent a highly prospective environment for the formation of magmatic Ni-Cu-PGE-Cr-V deposits and possibly played an important role in the formation of giant deposits such as the Platreef, Noril'sk, Jinchuan, and Panzihua.

Acknowledgements The authors would like to thank the Nkomati Mine for granting access to their properties and samples. A.P. Dickin at McMaster University, Canada, is thanked for offering access to analytical facilities to S Prevec for the Nd isotope analyses. A. Wilson and R. Latypov provided very useful reviews, as did associate editor M. Fiorentini and editor G. Beaudoin.

Open Access This article is distributed under the terms of the Creative Commons Attribution 4.0 International License (http:// creativecommons.org/licenses/by/4.0/), which permits unrestricted use, distribution, and reproduction in any medium, provided you give appropriate credit to the original author(s) and the source, provide a link to the Creative Commons license, and indicate if changes were made.

\section{References}

Barnes S-J, Zientek ML, Severson MJ (1997) Ni, Cu, Au, and platinumgroup element contents of sulphides associated with intraplate magmatism: a synthesis. Can J Earth Sci 34:337-351

Barnes S-J, Maier WD, Curl E (2010) Composition of the marginal rocks and sills of the Rustenburg layered suite, Bushveld complex, South Africa: implications for the formation of the PGE deposits. Econ Geol 105:1491-1511

Bowring JF, McLean NM, Bowring SA (2011) Engineering cyber infrastructure for $\mathrm{U}-\mathrm{Pb}$ geochronology: Tripoli and $\mathrm{U}-\mathrm{Pb}$ Redux. Geochem Geophys Geosys 12:1-19

Buchanan PC, Reimold WU, Koeberl C, Kruger FJ (2004) Rb-Sr and $\mathrm{Sm}-\mathrm{Nd}$ isotopic compositions of the Rooiberg group, South Africa: early bushveld-related volcanism. Lithos 29:373-388

Cameron EM (1982) Sulphate and sulphate reduction in early Precambrian oceans. Nature 296:145-148

Condon DJ, Mclean NM, Schoene B, Bowring S, Parrish R, Noble SR (2008) Synthetic U-Pb 'standard' solutions for ID-TIMS geochronology. Geochim Cosmochim Acta 72(12S):A175

De Waal SA, Maier WD, Armstrong RA, Gauert CDK (2001) Parental magma and emplacement of the stratiform Uitkomst complex. Can Mineralogist 39:557-571
DePaolo DJ (1981) Neodymium isotopes in the Colorado front range and crust-mantle evolution in the Proterozoic. Nature 291:193-196

Ertel W, O’Neill HSC, Sylvester PJ, Dingwell DB (1999) Solubilities of $\mathrm{Pt}$ and $\mathrm{Rh}$ in a haplobasaltic melt at $1300^{\circ} \mathrm{C}$. Geochim Cosmochim Acta 63:2439-2449

Finnigan CS, Brenan JM, Mungall JE, McDonough WF (2008) Experiments and models bearing on the role of chromite as a collector of platinum group minerals by local reduction. J Petrol 49: $1647-1665$

Fonseca ROC, Campbell IH, O’Neill HSC, Allen CM (2009) Solubility of $\mathrm{Pt}$ in sulphide mattes: implications for the genesis of PGE-rich horizons in layered intrusions. Geochim Cosmochim Acta 73:57645777

Francis D (1994) Chemical interaction between Picritic magmas and upper crust along the margins of the Muskox intrusion, northwest territories. Geol Surv Can Pap:92-12 94 pp

Ganino C, Arndt NT, Zhou M-F, Gaillard F, Chauvel C (2008) Interaction of magma with sedimentary wall rock and magnetite ore genesis in the Panzhihua mafic intrusion, SW China. Mineral Deposita 43: 677-694

Gauert, CDK (1998) The petrogenesis of the Uitkomst Complex, Mpumalanga Province, South Africa. Unpubl PhD thesis, Univ Pretoria, $315 \mathrm{pp}$

Gauert CDK, de Waal SA, Wallmach T (1995) Geology of the ultrabasic to basic Uitkomst complex, eastern Transvaal, South Africa: an overview. J Afr Earth Sci 21:553-570

Gauert CDK, Jordaan LJ, de Waal SA, Wallmach T (1996) Isotopic constraints on the source of Sulphur for the base metal sulphides of the Uitkomst complex. Badplaas, South Africa: S Afr J Geol 99: $41-50$

Gomwe T (2002) A geochemical profile through the Uitkomst Complex on the farm Slaaihoek, with special reference to the platinum-group elements and Sm-Nd isotopes. Unpubl MSc thesis, Univ Pretoria, $107 \mathrm{pp}$

Harmer RE, Sharpe MR (1985) Field relation and strontium isotope systematics of the marginal rocks of the eastern bushveld complex. Econ Geol 80:813-837

Harris C, Chaumba JB (2001) Crustal contamination and fluid-rock interaction during the formation of the Platreef, northern limb of the Bushveld complex, South Africa. J Petrol 42:1321-1347

Harris C, Pronost JJM, Ashwal LD, Cawthorn RG (2005) Oxygen and hydrogen isotope stratigraphy of the Rustenburg layered suite, bushveld complex: constraints on crustal contamination. J Petrol 46:579601

Hiess J, Condon DJ, McLean N, Noble SR (2012) ${ }^{238} \mathrm{U} /{ }^{235} \mathrm{U}$ systematics in terrestrial uranium-bearing mineral. Nature 335:1610-1614

Hornsey AE (1999) The genesis and evolution of the Nkomati Mine Nisulphide deposit, Mpumalanga Province, South Africa. Unpubl MSc thesis, Univ Natal (Durban), 224 pp

Hulley V (2005) Reactions between country rock xenoliths and the magma of the Uitkomst Complex, with implications for the origin of the sulphide mineralization. Unpubl MSc thesis, Univ Pretoria, 117p

Jaffey AH, Flynn KF, Glendenin LE, Bentley WC, Essling AM (1971) Precision measurements of half-lives and specific activities of ${ }^{235} \mathrm{U}$ and ${ }^{238}$ U. Physical Reviews C 4(5):1889-1906

Kinnaird JA (2005) Geochemical evidence for multiphase emplacement in the southern Platreef. Trans IMM 114:B225-B242

Klein C, Beukes NJ (1989) Geochemistry and sedimentology of the facies transition from limestone to iron-formation deposition in the early Proterozoic Transvaal Supergroup, South Africa. Econ Geol 84:1733-1774

Lahaye Y, Arndt N, Byerly G, Chauvel C, Fourcade S, Gruau G (1995) The influence of alteration on the trace element and $\mathrm{Nd}$ isotopic compositions of komatiites. Chem Geol 126:43-64

Lehmann J, Arndt NT, Windley B, Zhou M-F, Wang C, Harris C (2007) Field relationships and geochemical constraints on the emplacement 
of the Jinchuan intrusion and its Ni-Cu-PGE sulfide deposit, Gansu, China. Econ Geol 102:75-94

Lesher CE, Spera FJ (2015) Thermodynamic and transport properties of silicate melts and magma. The Encyclopedia of Volcanoes:113-141

Li C, Ripley EM, Maier WD, Gomwe TES (2002) Olivine and sulfur isotopic compositions of the Uitkomst $\mathrm{Ni}-\mathrm{Cu}$ sulfide ore-bearing complex, South Africa: evidence for sulfur contamination and multiple magma emplacements. Chem Geol 188:149-159

Lowry D, Mattey DP, Harris JW (1999) Oxygen isotope compositions of syngenetic inclusions in diamond from the Finsch mine, RSA. Geochim Cosmochim Acta 63:1825-1836

MacGregor ID, Manton WI (1986) Roberts victor eclogites: ancient oceanic crust. J Geophys Res 91:14063-14079

Maier WD, Barnes S-J (2004) Pt/Pd and Pd/Ir ratios in mantle-derived magmas: a possible role for mantle metasomatism. S Afr J Geol 107: $333-340$

Maier WD, Arndt NT, Curl EA (2000) Progressive crustal contamination of the bushveld complex: evidence from $\mathrm{Nd}$ isotopic analyses of the cumulate rocks. Contrib Mineral Petrol 140:316-327

Maier WD, Gomwe T, Barnes S-J, Li C, Theart H (2004) Platinum-group elements in the Uitkomst complex. South Africa, Econ Geol 99: 499-516

Maier WD, Barnes S-J, Groves DI (2013) The Bushveld complex, South Africa: formation of platinum-palladium, chrome and vanadiumrich layers via hydrodynamic sorting of a mobilized cumulate slurry in a large, relatively slowly cooling, subsiding magma chamber. Min Deposita 48:1-56

Maier WD, Rasmussen B, Fletcher I, Godel B, Barnes SJ, Fisher L, Yang S, Huhma H, Lahaye Y (2015) Petrogenesis of the 2.77 Ga Monts de Cristal complex, Gabon: evidence for direct precipitation of Ptarsenides from basaltic magma. J Petrol 56:1285-1308

Maier WD, Barnes S-J, Karykowski BT (2016) A chilled margin of komatiite and Mg-rich basaltic andesite in the western Bushveld complex, South Africa. Contrib Mineral Petrol 171:57. doi:10.1007/s00410-016-1257-5

Mattinson JM (2005) Zircon U-Pb chemical abrasion ("CA-TIMS") method: ombined annealing and multi-step partial dissolution analysis for improved precision and accuracy of zircon ages. Chem Geol 220:47-46

Mattinson JM (2010) Analysis of the relative decay constants of ${ }^{235} \mathrm{U}$ and ${ }^{238} \mathrm{U}$ by multi-step CA-TIMS measurements of closed-system natural zircon samples. Chem Geol 275:186-198

McDonald I, Holwell DA (2011) Geology of the northern Bushveld complex and the setting and genesis of the Platreef Ni-Cu-PGE deposit. In Li C, Ripley EM (eds) magmatic Ni-Cu and PGE deposits: geology, geochemistry, and genesis. Rev Econ Geol 17:297-327

Mudd GM (2012) Key trends in the resource sustainability of platinumgroup elements. Ore Geol Rev 46:106-117

Murck BW, Campbell IH (1986) The effects of temperature, oxygen fugacity and melt composition on the behavior of chromium in basic and ultrabasic melts. Geochim Cosmochim Acta 50:1871-1887

Naldrett AJ, Li C (2009) Ore deposits related to flood basalts. In: Li C, Ripley EM (eds) New developments in magmatic Ni-Cu and PGE deposits. Geological Publishing House, Beijing 290pp

Oosthuysen EJ (1970) The geochronology of a suite of rocks from the granitic terrain surrounding the Barberton Mountain Land. Unpubl $\mathrm{PhD}$ thesis, Univ Witwatersrand, Johannesburg.

Piña R, Romeo I, Ortega L, Lunar R, Capote R, Gervilla F, Tejero R, Quesada C (2009) Origin and emplacement of the Aguablanca magmatic Ni-Cu-(PGE) sulfide deposit, SW Iberia: A multidisciplinary approach, GSA bulletin, doi: 10.1130/B30046.1

Prevec SA, McNutt RH, Dickin AP (1991) Sr and Nd isotopic and petrological evidence for the age and origin of the white bear arm complex and associated units from the Grenville Province in eastern Labrador in mid-Proterozoic Laurentica-Baltica. In: Gower CF, Rivers T, Ryan B (eds) Geol Assoc Can, Spec Pap, vol 38, pp 65-78
Richardson SH, Shirey SB (2008) Continental mantle signature of Bushveld magmas and coeval diamonds. Nature 453:910-913

Richardson SH, Gurney JJ, Erlank AJ, Harris JW (1984) Origin of diamonds in old enriched mantle. Nature 310:198-202

Richardson SH, Harris JW, Gurney JJ (1993) Three generations of diamonds from old continental mantle. Nature 366:256-258

Rioux M, Bowring SA, Dudás F, Hanson R (2010) Characterizing the U$\mathrm{Pb}$ systematics of baddeleyite through chemical abrasion: application of multi-step digestion methods to baddeleyite geochronology. Contrib Mineral Petrol 160:777-801

Roberts G (2015) PGE contents across the Pyroxenite Unit, Uitkomst Complex. Unpubl. MSci dissertation, Cardiff University

Sarkar A, Ripley EM, Li C, Maier WD (2008) Stable isotope, fluid inclusion, and mineral chemistry constraints on contamination and hydrothermal alteration in the Uitkomst complex, South Africa. Chem Geol 257:129-138

Saumur BM, Cruden AR, Evans-Lamswood DM, Lightfoot PC (2015) Wall-rock structural controls on the genesis of the Voisey's bay intrusion and its $\mathrm{Ni}-\mathrm{Cu}-\mathrm{Co}$ magmatic sulfide mineralization (Labrador, Canada). Econ Geol 110:691-711

Schmitz MD, Schoene B (2007) Derivation of isotope ratios, errors, and error correlations for U-Pb geochronology using $205 \mathrm{~Pb}-235 \mathrm{U}$ (233 U)-spiked isotope dilution thermal ionization mass spectrometric data. Geochemistry Geophysics Geosystems 8(8). doi:10.1029 $12006 \mathrm{GC} 001492$

Schoene B (2014) U-Th-Pb geochronology. Treatise on geochemistry, 2nd edn. Elsevier Ltd., Amsterdam, pp 341-378

Schoene B, Crowley JL, Condon DJ, Schmitz MD, Bowring SA (2006) Reassessing the uranium decay constants for geochronology using ID-TIMS U-Pb data. Geochim Cosmochim Acta 70:426-445

Schoene B, Dudas FO, Bowring SA, de Wit M (2009) Sm-Nd isotopic mapping of lithospheric growth and stabilization in the eastern Kaapvaal craton. Terra Nov. 21:219-228

Scoates JS, Friedman RM (2008) Precise age of the platiniferous Merensky reef, Bushveld complex, South Africa, by the U-Pb zircon chemical abrasion ID-TIMS technique. Econ Geol 103:465-471

Scoates JS, Wall CJ (2015) Geochronology of layered intrusions. In: Charlier B et al (eds) Layered intrusions. Springer Science, Netherlands, pp 3-74

Sun S-s, McDonough, WF (1989) Chemical and isotopic systematics of oceanic basalts: implications for mantle composition and processes. In: Saunders AD, Norry MJ (Eds.), Magmatism in the Ocean Basins, vol. 42. Geological Society Special Publication, London, UK, pp. 313-345

Swart QD (1999) Carbonate rocks of the Paleoproterozoic Pretoria and Postmasburg Groups, Transvaal Supergroup: MS thesis, Rand Afrikaans University, Johannesburg, South Africa, 126p

Teigler B, Eales HV (1996) The Lower and Critical zones of the western limb of the Bushveld Complex, as indicated by the Nooitgedacht boreholes. Geol Surv S Afr Bull 111: 126 pp

Theart HFJ, De Nooy CD (2001) The platinum-group minerals in two parts of the massive sulphide body of the Uitkomst complex, Mpumalanga, South Africa. S Afr J Geol 104:287-300

Valley JW, Kinny PD, Schulze DJ, Spicuzza MJ (1998) Zircon megacrysts from kimberlite: oxygen isotope variability among mantle melts. Contrib Mineral Petrol 133:1-11

Von Scheibler WHTM, Cawthorn RG, Kenyon AK, Allen IVM (1995) $\mathrm{Ni}-\mathrm{Cu}$ sulfide mineralization in the Uitkomst intrusion. Geol Soc $\mathrm{S}$ Afr, centennial Geocongress '95. Ext Abstr 1:133-136

Wabo H, Olsson JR, De Kock MO, Humbert F, Soderlund U, Klausen MB (2015) New U-Pb age and paleomagnetic constriants from the Uitkomst complex, South Africa: clues to the timing of intrusion. GFF. doi:10.1080/11035897.2015.1098726

Wager LR, Brown GM (1968) Layered igneous rocks: Edinburgh and London, UK, Oliver and Boyd, 588 p 
Walraven F, Martini J (1995) Zircon Pb-evaporation age determinations of the oak tree formation, Chuniespoort group, Transvaal sequence: implications for Transvaal-Griqualand west basin correlations. S Afr J Geol 98:58-67

Wasserburg GJ, Jacobsen SB, DePaolo DJ, McCulloch MT, Wen T (1981) Precise determination of $\mathrm{Sm} / \mathrm{Nd}$ ratios, $\mathrm{Sm}$ and $\mathrm{Nd}$ isotopic abundances in standard solutions. Geochim Cosmochim Acta 45: 2311-2323

Wenzel T, Baumgartner LP, Brügmann GE, Konnikov EG, Kislov EV (2002) Partial melting and assimilation of dolomitic xenoliths by mafic magma: the Ioko-Dovyren intrusion (north Baikal region, Russia). J Petrol 43:2049-2074
Wilson AH (2012) A chill sequence to the bushveld complex: insight into the first stage of emplacement and implications for the parental magmas. J Petrol 53:1123-1168

Wyllie PJ, Tuttle OF (1960) The system CaO-CO2-H2O and the origin of carbonatites. J Petrol 1:1-46

Yudovskaya MA, Naldrett AJ, Woolfe JAS, Costin G, Kinnaird JA (2015) Reverse compositional zoning in the Uitkomst chromitites as an indication of crystallisation in a magmatic conduit. J Petrol 56: 2373-2394

Zeh A, Ovtcharova M, Wilson AH, Schaltegger U (2015) The Bushveld complex was emplaced and cooled in less than one million yearsresults of zirconology and geotectonic implications. Earth Planet Sci Lett 418:103-114 